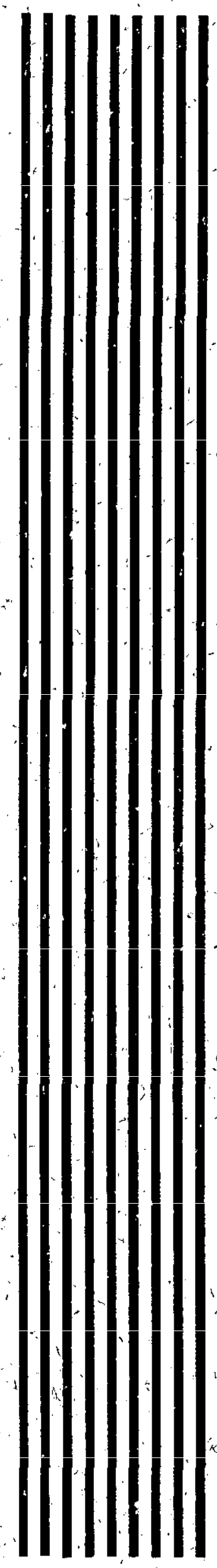

DOE/EA - 1164

\title{
ENVIRONMENTAL ASSESSMENT FOR THE \\ CLOSURE OF THE HIGH-LEVEL WASTE TANKS IN F- \& H-AREAS \\ AT THE \\ SAVANNAH RIVER SITE
}

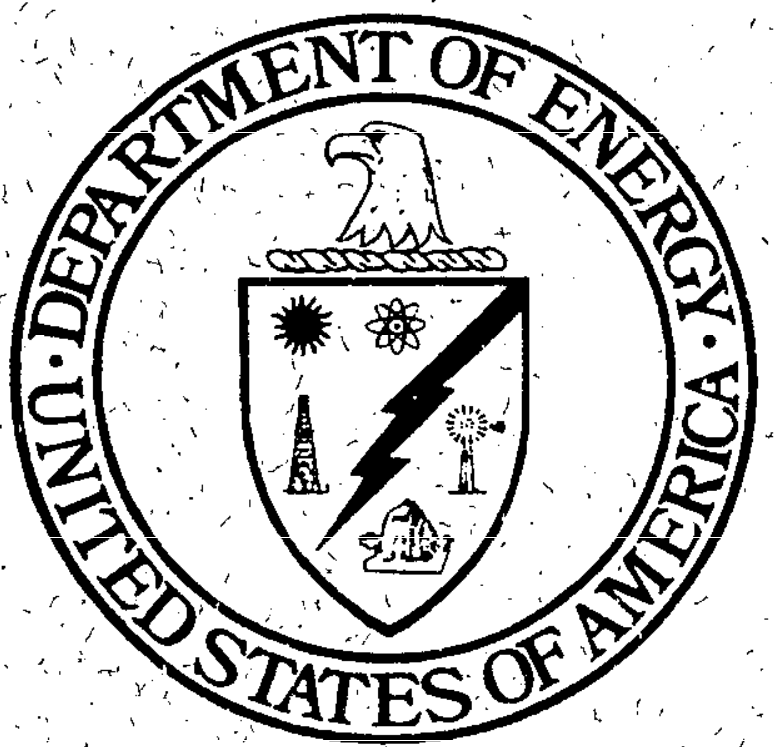

JULY 1996

UNITED STATES DEPARTMENT OF EÑERGY SAVANNAH RIVER OPERATIONS OFFICE SA VANNAH RIVER SITTE 
DOE/EA-1164

\section{ENVIRONMENTAL ASSESSMENT FOR THE CLOSURE OF THE HIGH-LEVEL WASTE TANKS IN F- \& H-AREAS AT THE SAVANNAH RIVER SITE}

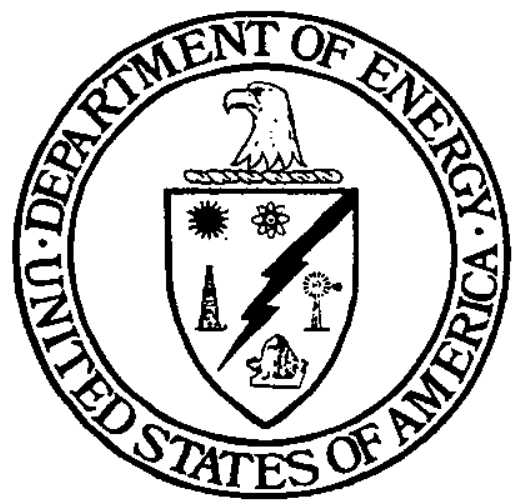

JULY 1996

UNITED STATES DEPARTMENT OF ENERGY SAVANNAH RIVER OPERATIONS OFFICE SAVANNAH RIVER SITE 


\section{TABLE OF CONTENTS}

1.0 INTRODUCTION

$1.1 \quad$ Background.................................................

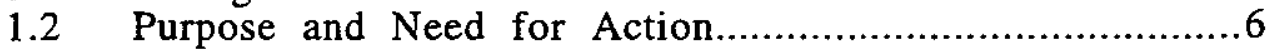

2.0 PROPOSED ACTION AND ALTERNATTVES ........................6

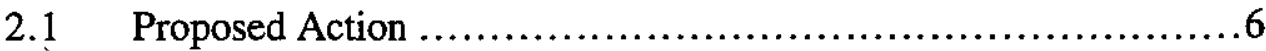

2.1.1 Bulk Waste Removal, Clean, Fill Tanks With

Pumpable Backfill Material (Preferred Alternative).........7

2.1.2 Bulk Waste Removal, Clean, Fill Tanks With Sand..........8

2.1.3 Bulk Waste Removal, Clean, Fill Tanks With Saltstone....9

2.2 Alternatives to the Proposed Action ...........................9

2.2.1 No Action, Bulk Waste Removal, No Fill Material, Abandonment .......................................... 10

2.2.2 Clean to Extent Allowing Removal of the Tanks.............10

2.2.3 Other Technologies....................................11

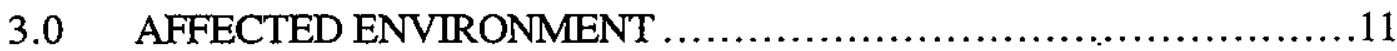

3.1 Land Use....................................................

3.2 Regional Demographics.....................................12

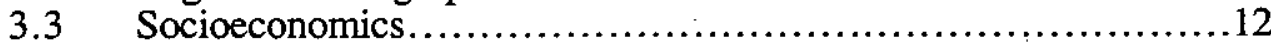

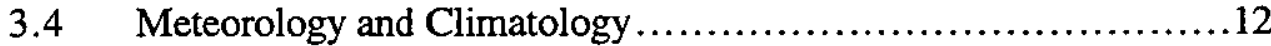

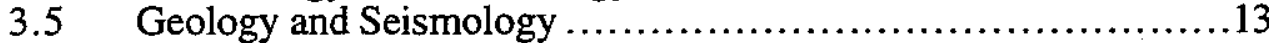

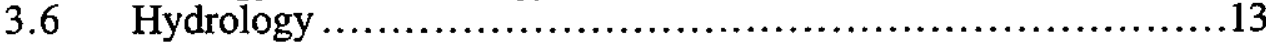

3.7 Ecological and Cultural Resources...................................13

$3.8 \quad$ Radiation Environment ...................................

4.0 ENVIRONMENTAL CONSEQUENCES OF THE PROPOSED

ACTION AND ALTERNATIVES ..........................................15

4.1 Tank System Closure.............................................15

4.2 Post-Tank Closure.................................................16

4.3 Human Health Effects......................................... 17

4.4 Transportation Impact Analysis ...............................18

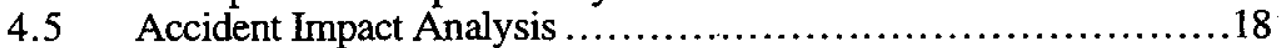

4.6 Environmental Consequences of the Alternatives................19

4.7 Cumulative Impacts.........................................19

5.0 REGULATORY AND PERMITTING PROVISION

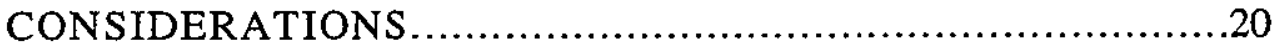

5.1 National Environmental Policy Act of 1969, as Amended (42 USC 4321 et seq.).........................................20

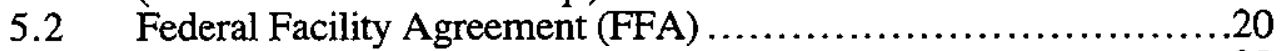

5.3 Industrial Wastewater .........................................

5.4 Additional Regulatory And Permitting Provisions ................21 


\section{LIST OF FIGURES}

Figure 1-1. Location of the F-Area and H-Area Tank Farm Facilities at the Savannah River Site, South Carolina.................... 2

Figure 1-2. F-Area liquid high-level waste tank farm................... 3

Figure 1-3. H-Area liquid high-level waste tank farm....................4

Figure 1-4. Regulatory Coverage...................................6

Figure 3-1. Location of seismic faults at the Savannah River Site, South Carolina.

Figure A-1. Simplified HLW System Flowsheet.

A-2

Figure A-2. Type I Waste Tank--2,839,059 l (750,000 gal) capacity

Figure A-3. Type II Waste Tank--3,898,974 l (1,030,000 gal) capacity

Figure A-4. Type III Waste Tank--4,921,035 l (1,300,000 gal) capacity

Figure A-5. Type IV Waste Tank--4,921,035 l (1,300,000 gal) capacity

Figure B-1. Typical tank closure configuration. B-2

APPENDIXES:

APPENDIX A: $\quad$ High-Level Waste System Description.............A-1

APPENDEX B: Closure Configuration........................... B-1

APPENDIX C: $\quad$ Comparative Analyses of Pre-closure HLW Tank Operations and Post Cloure Conditions.....C-1

APPENDIX D Response to Public Comments.....................

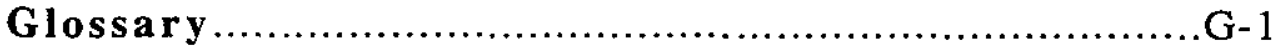

Acronyms and Abbreviations............................. G-3 


\subsection{INTRODUCTION}

This Environmental Assessment (EA) has been prepared by the Department of Energy (DOE) to assess the potential environmental impacts associated with the closure of 51 high-level radioactive waste tanks and tank farm ancillary equipment (including transfer lines, evaporators, filters, pumps, etc) at the Savannah River Site (SRS) located near Aiken, South Carolina (Figure 1-1). The waste tanks are located in the F- and H-Areas (Figures 1-2 and 1-3) of SRS and vary in capacity from 2,839,059 liters (750,000 gallons) to $4,921,035$ liters $(1,300,000$ gallons). These in-ground tanks are surrounded by soil to provide shielding.

The F- and H-Area High-Level Waste Tanks are operated under the authority of Industrial Wastewater Permits \#17,424-IW; \#14520, and \#14338 issued by the South Carolina Department of Health and Environmental Control (SCDHEC). In accordance with the Permit requirements, DOE has prepared a Closure Plan (DOE, 1996) and submitted it to SCDHEC for approval. The Closure Plan identifies all applicable or relevant and appropriate regulations, statutes, and DOE Orders for closing systems operated under the Industrial Wastewater Permits. When approved by SCDHEC, the Closure Plan will present the regulatory process for closing all of the F- and H-Area High Level Waste Tanks. The Closure Plan establishes performance objectives or criteria to be met prior to closing any tank, group of tanks, or ancillary tank farm equipment.

The proposed action is to remove the residual wastes from the tanks and to fill the tanks with a material to prevent future collapse and bind up residual waste, to lower human health risks, and to increase safety in and around the tanks. If required, an engineered cap consisting of clay, backfill (soil), and vegetation as the final layer to prevent erosion would be applied over the tanks. The selection of tank system closure method will be evaluated against the following Comprehensive Environmental Response, Compensation, and Liability Act (CERCLA) criteria described in 40 CFR 300.430(e)(9): (1) overall protection of human health and the environment; (2) compliance with applicable or relevant and appropriated requirements (ARARs); (3) long-term effectiveness and permanence; (4) reduction of toxicity, mobility, or volume through treatment; (5) short-term effectiveness; (6) implementability; (7) cost; (8) state acceptable; and (9) community acceptance.

Closure of each tank involves two separate operations after bulk waste removal has been accomplished: 1) cleaning of the tank (i.e., removing the residual contaminants), and 2) the actual closure or filling of the tank with an inert material, (e.g., grout). This process would continue until all the tanks and ancillary equipment and systems have been closed. This is expected to be about year 2028 for Type I, II, and IV tanks and associated systems. Subsequent to that, Type III tanks and systems will be closed.

Thus, the 24 Type I, II, and IV tanks would be removed from service while the 27 Type III tanks would remain in service until there is no further need for the tanks or the wastes have been consolidated into other tanks. When waste processing is complete and the last tank closed, the remaining waste processing systems would be closed.

The environmental impacts of operation of the tank farms, including bulk waste removal, are evaluated in the Defense Waste Processing Facility Supplemental Environmental Impact Statement (DOE, 1994) and the Waste Management Environmental Impact Statement (DOE, 1995a). Potential impacts to the soil from contaminants already present around the sides of the tanks or under the tanks from previous leaks or spills are not addressed in this EA as they are already covered under CERCLA. Remediation of these impacts would be evaluated in other environmental restoration activities scheduled for the site. 


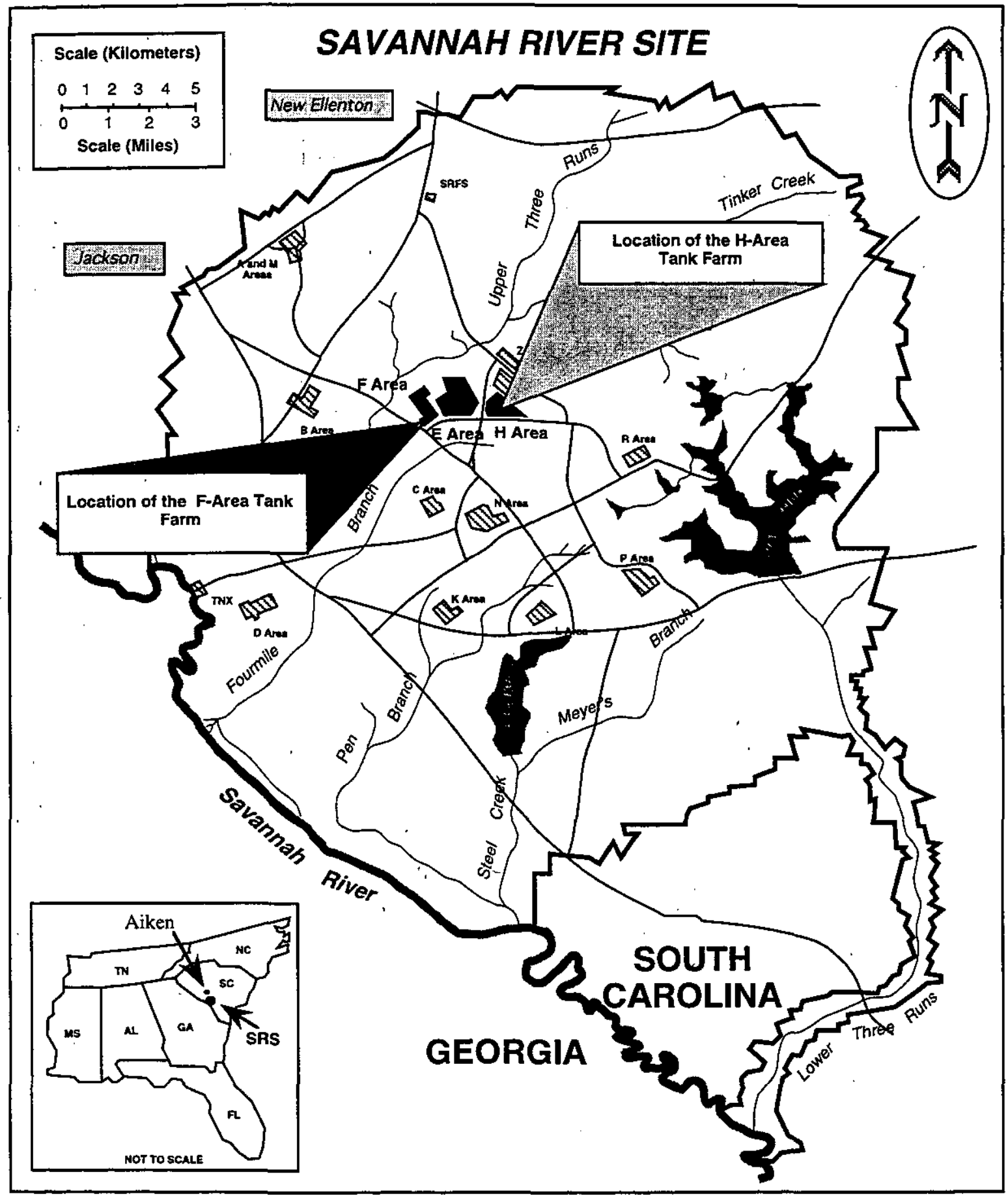

Figure 1-1. Locations of the F-Area and H-Area Tank Farms at the Savannah River Site, South Carolina. 


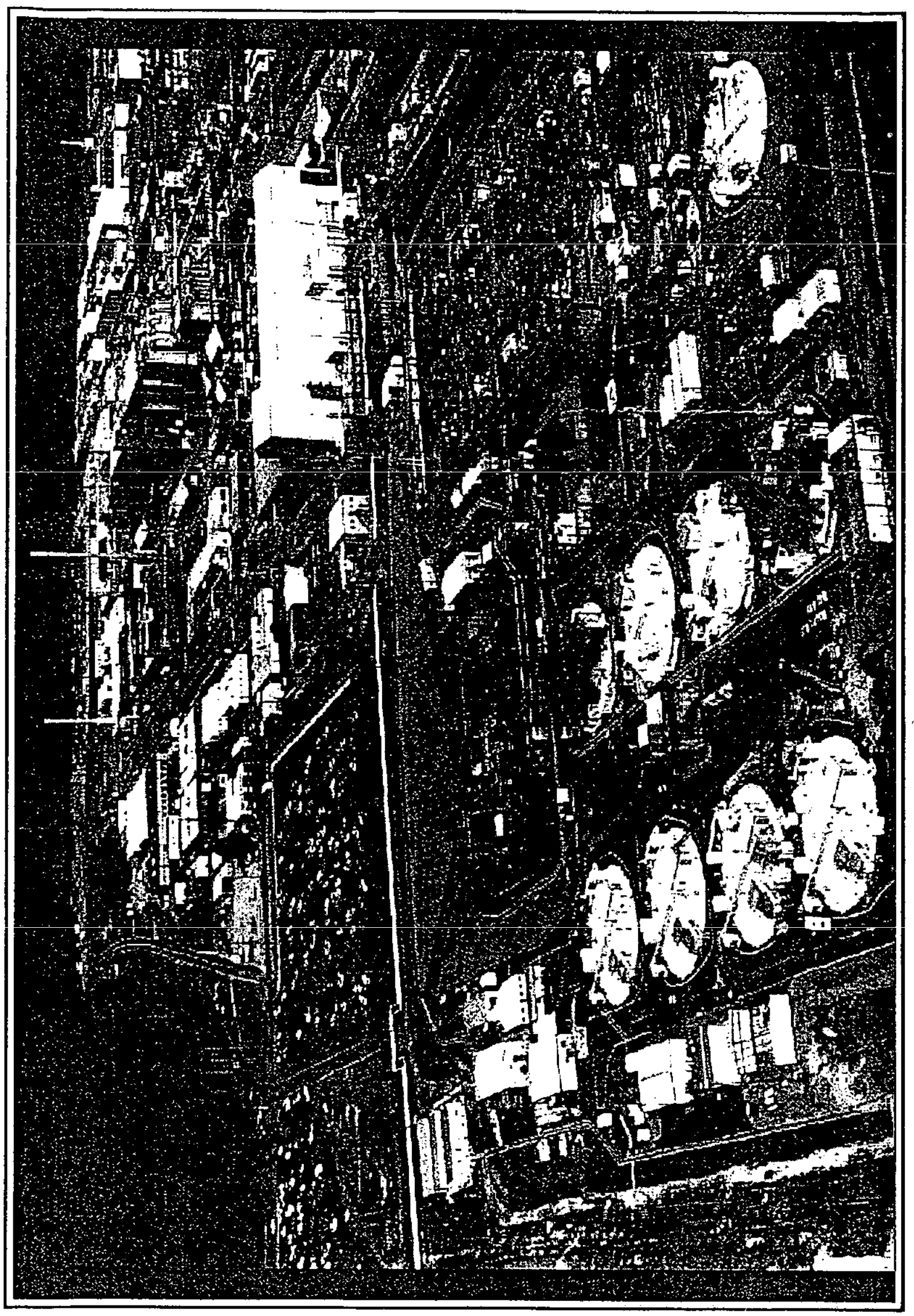

है 


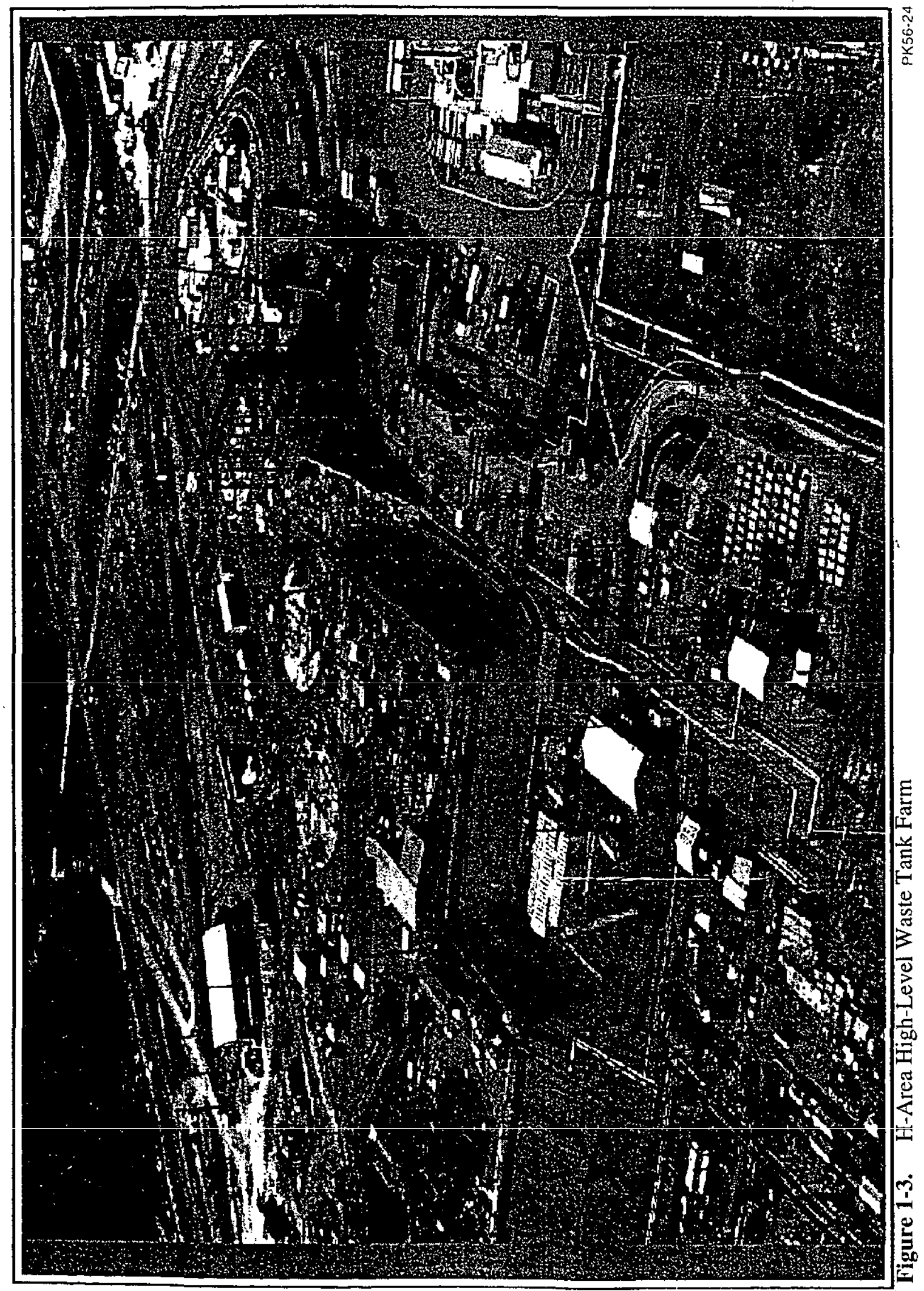


This document was prepared in compliance with the National Environmental Policy Act (NEPA) of 1969, as amended, the Council on Environmental Quality Regulations for Implementing NEPA (40 CFR 1500-1508), and the DOE Regulation for implementing NEPA (10 CFR 1021). NEPA requires the assessment of environmental consequences of Federal actions that may affect the quality of the human environment. Based on the potential for impacts described herein, DOE will either publish a Finding of No Significant Impact (FONSI) or prepare an Environmental Impact Statement (EIS).

\subsection{Background}

When established in the early 1950s, SRS's primary mission was to produce special nuclear materials to support the defense, research, and medical programs of the United States. SRS's present mission emphasizes waste management, environmental restoration, and decontamination and decommissioning of facilities that are no longer needed for SRS's traditional defense mission. Chemical separation of irradiated fuel and targets at SRS resulted in product streams and acidic liquid streams that contained almost all of the fission products and small amounts of transuranics. This waste was chemically converted to an alkaline solution and stored in large underground tanks at the SRS F- and H-Area Tank Farms (Figures 1-2 and 1-3) as insoluble sludges, precipitated salts, and supernate (liquid) (DOE, 1982).

At the present time the approximately 129 million liters ( 34 million gallons) of High-Level Waste (HLW) are being treated to separate the high-activity fraction (a sludge) from the low-activity fraction (a liquid). The high-activity fraction is transferred to the Defense Waste Processing Facility (DWPF) for vitrification in borosilicate glass to immobilize the radioactive constituents for long term storage. Final disposal of the vitrified waste will proceed after the transfer to a federal repository. The low-activity fraction is transferred to Z-Area and mixed with grout to make saltstone, a concrete-like material disposed of in vaults. The environmental impacts of these processes and facilities were evaluated in the DWPF Supplemental Environmental Impact Statement (DOE, 1994) and Waste Management Environmental Impact Statement (DOE, 1995a). A more detailed description of the systems and processes of interest is provided in Appendix A, High-Level Waste System Description in this EA and in the above referenced EISs (DOE, 1994; DOE, 1995a).

After the bulk waste has been removed from the tanks for treatment and disposal, the tank systems would become part of the tank systems closure project (Figure 1-4), the potential environmental impacts of which are the subject of this EA. The primary concerns are how to deal with the waste that cannot be removed from the bottom of a tank (referred to as a heel) and tank stabilization methods. As outlined in the Closure Plan (DOE, 1996), DOE intends to close the tank systems to protect human health and the environment, and promote safety in and around these tank systems in accordance with South Carolina Regulation R.61-82, "Proper Closeout of Wastewater Treatment Facilities"

Upon completion of closure activities for geographical groups of tanks and waste handling systems, including evaporators, pumps, and transfer lines under this plan, portions of the High-Level Waste (HLW) tank farms would transition from the tank closure project to the SRS Environmental Restoration program. 


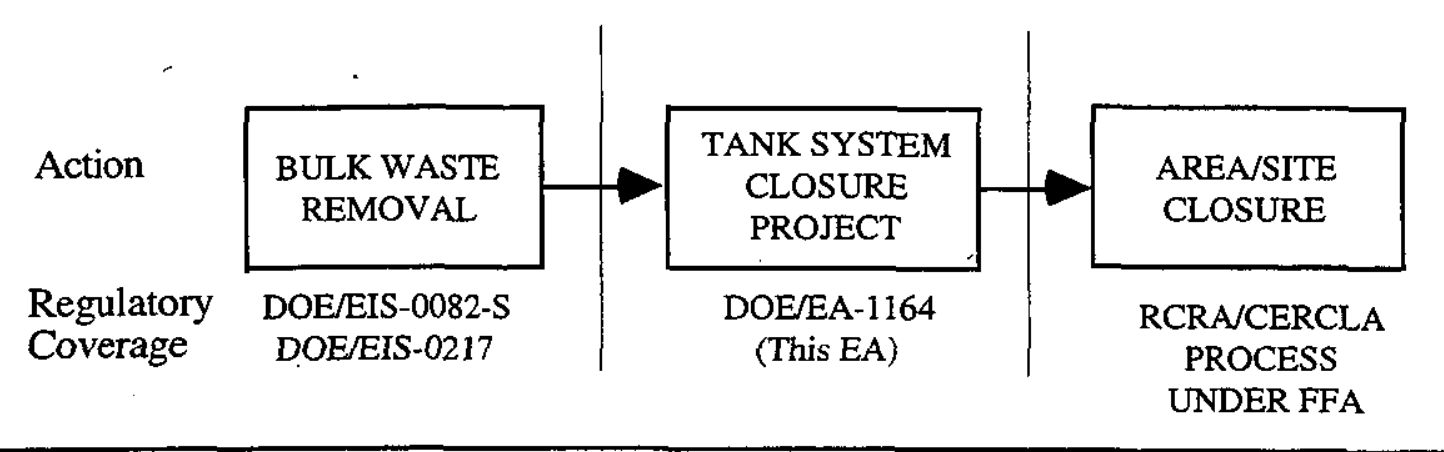

Figure 1-4. Regulatory coverage

\subsection{Purpose and Need for Action}

The purpose of DOE's proposed action is to close the $51 \mathrm{HLW}$ tanks in the F- and H-Area Tank Farms, after the current bulk waste inventory has been removed, to lower human health risks and to increase safety in and around the tanks. If the tanks are not stabilized, they would fail in the future, causing tank pollutants to enter the environment. DOE needs to decide on the best demonstrated technologies to close the tanks through appropriate evaluation of various alternatives in accordance with the Closure Plan approved by SCDHEC.

\subsection{PROPOSED ACTION AND ALTERNATIVES}

\subsection{Proposed Action}

The proposed action is to implement the Closure Plan approved by SCDHEC to remove the contaminants from the tank systems and to fill them with a structural material to prevent future collapse and bind up residual wastes. While the major focus of the closure activities is the HLW Tanks, the tank farms include other equipment for processing the waste, for example, evaporators, diversion boxes, pumps, and inter-area transfer lines which would be closed in a similar manner. Details of these systems are discussed in Appendix A and in the Closure Plan (DOE, 1996). The proposed action begins when bulk waste removal has been completed and the tank system is turned over to the tank closure project. A general protocol for closing the tank systems is outlined in the Closure Plan (DOE, 1996). The major steps in the tank closure project as outlined in the Closure Plan are:

\section{Evaluation and Cleaning Phase:}

- Determination of Performance Objectives - Environmental regulatory requirements and guidance would be used to develop closure standards that would be protective of human health and the environment. These would provide the regulatory basis for tank closure methods.

- Cleanup and Stabilization Selection - After waste removal, an evaluation would be conducted against the closure standards to determine the necessary cleaning and 
stabilization methods to be employed for the tank system closure. Waste generated by cleaning would be recycled through the HLW processing system.

\section{Approval Phase:}

- Closure Module Preparation and Approval - A tank system specific Closure Module would be developed that describes the end state of the tank, the performance modeling results, and closure details. The module would be submitted to SCDHEC and Environmental Protection Agency (EPA) for approval.

\section{Stabilization Phase:}

- Tank Stabilization - The details presented in the approved tank-specific Closure Module will be executed.

The closed tank system will then be turned over to the SRS Environmental Restoration Program.

To execute the proposed action, several alternatives were explored (all costs are in FY96 dollars):

\subsubsection{Bulk Waste Removal, Clean, Fill Tanks With Pumpable Backfill Material (Preferred Alternative)}

\section{Evaluation and Cleaning Phase}

Each tank or group of tanks, as appropriate, would be evaluated to determine the inventory of contaminants (radiological and nonradiological) present after bulk waste removal which includes spray washing. This information would be used to conduct a performance evaluation. This evaluation would take into account differences in the types of contamination and configurations of cooling coils and equipment, and the hydrogeologic configuration of the tanks, or group of tanks, such as distance from the water table, and distance to nearby streams. The performance evaluation includes modeling the projected contamination pathways for selected closure configurations and comparing the modeling results with the performance objectives developed in the Closure Plan (DOE, 1996). If the performance objectives are met, closure would continue to the stabilization phase.

If the performance objectives cannot be met additional cleaning steps such as additional spray washing, oxalic acid cleaning, or other cleaning techniques of comparable effectiveness would be taken, as required.

- Spray washing--This process involves spray washing each tank using rotary spray jets with hot water. The spray nozzles can remove waste near the edges of the tank that is not readily removed by slurry pumps. After spraying, the contents of the tank would be agitated with slurry pumps and pumped out of the tank. This process has been demonstrated on Tanks 16 and 17. The amount of waste left after spray washing was estimated at about 18,927 liters (3,500 gallons) in Tank 16 and about 15,142 liters (4,000 gallons) in Tank 17 (du Pont, 1980; WSRC, 1995a).

- Oxalic acid cleaning--In this process, after the spray washing is complete, hot oxalic acid would be sprayed through the spray nozzles that were used for spray washing. This process has been demonstrated on Tank 16 only. A number of potential cleaning agents for sludge removal were studied. Oxalic acid was chosen as the preferred 
cleaning agent because it dissolves sludge, and is only moderately aggressive against carbon steel, the material used in the construction of the waste tanks.

- Annulus cleaning--Nine tanks have leaked measurable amounts of waste from primary containment to secondary containment (WSRC, 1995b). For these tanks, the waste would be removed from the annulus using water and/or steam. Annulus cleaning has been attempted at SRS on only one tank (Tank 16), and the operation was only partially completed. Thus, annulus cleaning is not a demonstrated technology, and new techniques may need to be developed. The amount of waste in secondary containment is small, so the environmental risk of this waste is minimal compared to the amount of waste contained inside the tanks.

\section{Stabilization Phase}

After cleaning, each tank, ancillary equipment, tank annulus (if applicable), etc., would be filled with a pumpable, self-leveling backfill material. The fill material would be trucked to an area near the tank farm, batched if necessary, and pumped to the tank to be closed. The fill material would be high enough in $\mathrm{pH}$ to be compatible with the carbon steel walls of the waste tank. The fill material would be formulated with chemical properties that would retard the movement of radionuclides from the closed tank. Thus, the closure configuration for each tank, or group of tanks, would be determined case by case. Although the details of each individual closure would vary, any tank system closure under this alternative would have the following characteristics:

- The fill material is pumpable, self-leveling, designed to prevent future subsidence of the tank, and would fill voids to the extent practical, including equipment and secondary containment.

- The fill material would be formulated to reduce the migration of radionuclides.

- The fill configuration discourages inadvertent intrusion.

- The final closure configuration would meet performance objectives established by SCDHEC and EPA.

This alternative would cost approximately $\$ 2,500,000$ and would result in an estimated 10.2 man-rem of worker exposure per tank system (includes ancillary equipment) closed. A detailed description of this closure alternative can be found in Appendix B of this EA.

\subsubsection{Bulk Waste Removal, Clean, Fill Tanks With Sand}

\section{Evaluation and Cleaning Phase}

As in the preferred alternative, bulk waste would be removed and the tanks cleaned sufficiently, using the best demonstrated technology, to meet the performance objectives of the Closure Plan (DOE, 1996).

\section{Stabilization Phase}

This process is similar to the preferred alternative except sand would be used instead of pumpable, self-leveling materials. The sand would be carried by truck to an area near the tank farm and conveyed to the tank to be closed. 
Sand is readily available and inexpensive. However, its emplacement is more difficult than the pumpable, self-leveling material as it does not flow readily into voids. Any equipment/piping left on or inside the tank, that requires filling to eliminate the voids inside the device, would not be sufficiently filled. Over time, the sand would settle in the tank, creating additional void spaces. The dome would then become unsupported and would sag and crack. There would not be the catastrophic collapse as would be anticipated in the no-action case. The sand would tend to isolate the contamination from the environment to some extent and prevent winds from spreading the contaminants. However, water would flow readily through the sand. Also, sand is relatively inert and could not be formulated to retard the migration of radionuclides. Thus, the expected contamination levels in groundwater and surface streams, resulting from migration of residual contaminants, would be higher than for the preferred alternative.

This alternative would cost approximately $\$ 2,500,000$ and would result in an estimated 10.2 man-rem of exposure per tank system closed (DOE, 1996).

\subsubsection{Bulk Waste Removal, Clean, Fill Tanks With Saltstone}

\section{Evaluation and Cleaning Phase}

This alternative would also include bulk waste removal and cleaning to meet the performance objectives of the Closure Plan as discussed in the preferred alternative.

\section{Stabilization Phase}

The stabilization process is similar to the preferred alternative except, the fill material used would be saltstone. Saltstone is a low radioactivity fraction of HLW mixed with cement, flyash, and slag to form a concrete-like mixture. Z-Area is currently operating a Saltstone Facility, processing radioactive waste from In-Tank Precipitation (ITP) and Effluent Treatment Facility (ETF) for disposal in Z-Area. This alternative has the advantage of reducing the amount of Saltstone Landfill Area that would be required because any saltstone sent to a waste tank would not require a vault or other disposal technique.

This alternative has several disadvantages:

- The total amount of saltstone to be made to stabilize the low-activity fraction of HLW would probably be greater than $378,541,186$ liters (100 million gallons), which is considerably in excess of the capacity of the waste tanks. Saltstone sets up quickly, is radioactive, and would be impractical to ship by truck or pump to the tank farms. Thus, a Saltstone Mixing Facility would need to be constructed in F-Area, another one in $\mathrm{H}$-Area, and the existing Saltstone Facility in $\mathrm{Z}$-Area would still need to be operated (DOE, 1996).

- Filling the tank with a grout mixture that is contaminated with radionuclides would considerably complicate the project and increase worker radiation exposure, further adding to the expense (\$5,000,000 per tank) and risk (DOE, 1996).

\subsection{Alternatives to the Proposed Action}

In accordance with the NEPA regulations, DOE examined the following alternatives for the proposed action:

- No action; bulk waste removal, no fill material, abandonment 
- Clean tanks to the extent allowing removal of tanks

\subsubsection{No Action; Bulk Waste Removal, No Fill Material, Abandonment}

Under the no-action alternative, the bulk waste would be removed from the existing 51 HLW tanks. The tanks would contain a residual waste and ballast water (as required) and not be filled with backfill material. After some period of time, the reinforcing bar in the roof of the tank would rust, and the roof of the tank would fail, causing the structural integrity of the tanks to degrade. Rainwater would readily pour into the exposed hole, flushing contaminants from the residual waste in the tank and carrying these contaminants into the groundwater.

This alternative would be the least expense (i.e., approximately $\$ 56,000$ per tank), require the least amount of field work and associated exposure ( 2 man-rem), and would require 37 fewer workers per tank system. There would be no impact on surrounding tanks and no interruption of ongoing operations in the tank farm. Future inhabitants of the area would be exposed to the contamination in the tank, and injuries or fatalities could occur if an intruder ventured into the area of the tank and the roof were to collapse due to structural failure. Also, movement of the contaminants into the groundwater is most rapid with this alternative, and expected contamination levels in groundwater and surface streams would be higher than for the preferred alternative (see 2.1.1 above) since there would be no containing media (DOE, 1996).

This alternative would not be protective of human health and safety or of the environment.

\subsubsection{Clean to Extent Allowing Removal of the'Tanks}

\section{Evaluation and Cleaning Phase .}

No evaluation of migration of residual contaminants and consequent impacts would need to be performed as the contaminated portions of the tank would be completely removed from the ground. After waste removal, each sludge or salt tank would undergo additional cleaning beyond that contemplated in other alternatives, perhaps oxalic acid cleaning, mechanical cleaning, and additional steps (yet to be defined) until it is clean enough to be safely removed.

\section{Stabilization Phase}

The tank steel components would be cut up, removed, placed in approximately 3,900 B-25 burial boxes (DOE, 1996), and transported to the burial grounds for disposal.

The advantage of this alternative is that there is the potential to dispose of the contaminated tank components in a waste management facility that has better barriers to the migration of contamination than in the current tank farm location.

The disadvantages include:

- High radiation exposure to workers during the removal process ( 93 man-rem per tank versus 10.2 man-rem for the preferred alternative) (DOE, 1996)

- Extremely high cost $(\$ 50,000,000$ per tank - 20 times more expensive than the preferred alternative) (DOE, 1996)

- Considerable impact on tank farm operations 
- Has not been demonstrated on actual HLW tanks

- May need to build additional burial facilities

\subsubsection{Other Technologies}

Mechanical and chemical cleaning involving advanced techniques have not been demonstrated in actual HLW tanks. A number of techniques have been studied involving such technologies as robotic arms, wet-dry vacuum cleaners, and remote cutters. However, none of these techniques can be considered as viable options at this time. For example, no robotic arms have been demonstrated that could navigate through the forest of cooling coils that are found in most SRS waste tanks. Also, as mentioned previously, there are more aggressive cleaning agents than oxalic acid, (e.g., nitric acid). However, these cleaning agents have an unacceptable environmental risk because they attack the carbon steel wall of the waste tank, causing deterioration of the metal, and reducing the intact containment life of the tank.

Oxalic acid cleaning has been demonstrated to provide cleaning that is at least 10 times as effective as bulk sludge removal alone, and it is relatively compatible with existing waste removal plans and processes, although it generates large quantities of sodium oxalate that requires disposal.

DOE is actively sponsoring research on improved cleaning methods. If improved cleaning methods are developed that provide equal or superior cleaning effectiveness to those discussed in the preferred alternative, these cleaning methods may be substituted. For example, it would be beneficial to develop a cleaning method that does not generate large quantities of sodium oxalate, an additional waste that would require disposal, (as is the case with oxalic acid cleaning).

DOE is also evaluating using contaminated soils (in a soil-cement form) as a fill material.

\subsection{AFFECTED ENVIRONMENT}

SRS occupies an area of approximately $800 \mathrm{~km}^{2}\left(300 \mathrm{mi}^{2}\right)$ in southwestern South Carolina (Figure 1-1). The site borders the Savannah River for about $27 \mathrm{~km}$ (17 mi) near Augusta, Georgia, and Aiken and Barnwell, South Carolina. SRS contains five nuclear production reactor areas, two chemical separations facilities, waste treatment, storage and disposal facilities, and various supporting facilities. The Final Environmental Impact Statement (EIS) for Waste Management (DOE, 1995a) contains additional information on SRS areas and facilities.

\subsection{Land Use}

The F- and H-Tank Farms are highly industrialized and have been so since the 1950s when the site was established. The tank farm areas are situated in the north-central portion of SRS, bounded by Upper Three Runs to the north and Fourmile Branch to the south. Land within an eight kilometers (five mile) radius of these areas lies entirely within the SRS boundaries and is used for either industrial purposes or as forested Jand (DOE, 1994). Figures 1-2 and 1-3 are aerial photographs of the tank farm areas and give an indication of the industrial nature of each location. 
For modeling purposes, it is assumed that the SRS separations and environmental management areas (area between Fourmile Branch and Upper Three Runs) would continue to be under institutional control for the next 100 years, and after that the area would be zoned industrial for an indefinite period with deed restrictions on the use of the groundwater (DOE, 1996).

\subsection{Regional Demographics}

Within an $80 \mathrm{~km}(50 \mathrm{mi})$ radius of the center of SRS is a total resident population of approximately 730,000 . One major urban center, Augusta, Georgia (1990 population of 44,639) (renamed August-Richmond County in 1995 with a population greater than $150,000)$, lies about $40 \mathrm{~km}(25 \mathrm{mi})$ west-northwest of the site. Four other cities within the $80 \mathrm{~km}$ (50 mi) radius had 1990 populations greater than 13,000: Aiken, South Carolina, about $32 \mathrm{~km}(20 \mathrm{mi})$ north-northwest; Orangeburg, South Carolina, $77 \mathrm{~km}$ (48 mi) east-northeast; North Augusta, South Carolina, $37 \mathrm{~km}(23 \mathrm{mi})$ northwest; and Evans, Georgia, about $56 \mathrm{~km}(35 \mathrm{mi})$ west-northwest of the site. All other cities and towns have populations less than 7,000, the largest being Belvedere, South Carolina, followed by Red Bank, South Carolina, Waynesboro, Georgia, and Barnwell, South Carolina (WSRC, 1995c).

The industrial population, consisting primarily of the SRS work force, Vogtle Electric Generating Plant employees, and employees of 16 smaller industries located in or near Barnwell, Williston, New Ellenton, and Jackson, South Carolina, comprise a daily transient population of approximately 25,734. Most of this total population works Monday through Friday from about 8:00 a.m. to 4:00 p.m. These workers spend an average of about 45 hours per week at the worksite. The industrial population within a eight kilometer (five-mile) radius of $\mathrm{F}$ - and $\mathrm{H}$-Areas consists entirely of SRS employees at A/M-, B-, C-, N-, E-, F-, H-, K-, R-. S-, and Z-Areas (WSRC, 1995c).

\subsection{Socioeconomics}

The workforce to be employed in the tank closure operations would consist of approximately 37 individuals (du Pont, 1982). It is expected that all of this workforce would be composed of existing local workers rather than new workers immigrating into the SRS area. The workforce would consist of a mixture of current SRS employees already working on tank farm related activities or relocated from their present job assignments and construction workers. The Final EIS for Waste Management (DOE, 1995a) and the most recent socioeconomic survey of the six-county SRS area of influence (NUS, 1992) contains additional information on the areas surrounding SRS.

\subsection{Meteorology and Climatology}

The SRS region has a temperate climate with mild winters and long summers. The average annual rainfall at SRS is about $122 \mathrm{~cm}$ (48 in) and the average wind speed in 1987-91 was $13.7 \mathrm{~km} / \mathrm{h}(8.5 \mathrm{mi} / \mathrm{h}$ ) (WSRC, 1989; DOE, 1995a). Tornadoes have been observed during every month of the year in the area encompassing SRS, but occur most frequently in the spring (WSRC, 1989). Only a few instances of slight to moderate tornado damage to support facilities have been documented for the site to date. The Reactor Operation Environmental Information Document, Volume III: Meteorology, Surface Hydrology, Transport and Impacts (WSRC, 1989) contains additional information on SRS meteorology and climatology. The general meteorological and climatological data for SRS would be representative of that for the F- and H-Tank Farm areas. 


\subsection{Geology and Seismology}

SRS is located in the Aiken Plateau physiographic region of the upper Atlantic Coastal Plain approximately $40 \mathrm{~km}(25 \mathrm{mi})$ southeast of the Fall Line which separates the Piedmont Plateau from the Atlantic Coastal Plain. The topographic surface of the coastal plain slopes gently seaward and is underlain by a wedge of seaward-dipping unconsolidated and semiconsolidated sediments from the Fall Line to the coast of South Carolina. Figure 3-1 shows SRS fault locations and a recent EIS (DOE, 1995a) contains additional information on SRS fault location and earthquake occurrences.

The principal surface and near-surface soils in $\mathrm{F}$ - and $\mathrm{H}$-Area are clayey sands averaging about one-third clay. These soils have demonstrated a good retention capacity for most radionuclides (Parsons, 1996). The stratigraphic layer which comprises the vadose zone is the Hawthorn Formation or Upland Unit. Extending over much of SRS, this formation contains predominantly red-brown to yellow-orange, coarse to fine sand, and silty clay with localized gravel lenses. The thickness of the Hawthorn Formation ranges, from $4.9 \mathrm{~m}$ $(16 \mathrm{ft})$ to $12.2 \mathrm{~m} \mathrm{(40} \mathrm{ft)} \mathrm{in} \mathrm{the} \mathrm{vicinity} \mathrm{of} \mathrm{the} \mathrm{F-} \mathrm{and} \mathrm{H-Areas} \mathrm{Seepage} \mathrm{Basins} \mathrm{(WSRC,}$ 1991) which are southwest and west of the F- and H-Area Tank Farms, respectively.

A notable feature of the Hawthom Formation is its compositional variability. Lenses of clay, sand, and sandy clay occur throughout the layer. The unit is traversed by small scale joints and fractures, both of which are commonly filled with sand or silt. The soils at F- and H-Area are 20 percent to 40 percent clay. The dominant clay mineral is kaolinite, with small amounts of other clays and weathered mica (WSRC, 1991).

\subsection{Hydrology}

The Savannah River forms the western boundary of SRS and receives drainage from five major tributaries on the site: Upper Three Runs, Fourmile Branch, Pen Branch, Steel Creek, and Lower Three Runs. These tributaries receive varying types of wastewater discharges from plant processes and sanitary treatment systems, all of which are permitted through the National Pollutant Discharge Elimination System (NPDES). On SRS, various plant processes also require the pumping of Savannah River water and/or on-site groundwater. A recent EIS (DOE, 1995a) contains information on groundwater systems on SRS and in the surrounding region.

The F-Area Tank Farm is on a near-surface groundwater divide between Upper Three Runs and Fourmile Branch. The near-surface groundwater from the southern part of the F-Area Tank Farm discharges to Fourmile Branch, approximately $1,524 \mathrm{~m}(5,000 \mathrm{ft})$ to the southwest. The near-surface groundwater from the northern part of the F-Area Tank Farm discharges to Upper Three Runs, approximately $1,372 \mathrm{~m}(4,500 \mathrm{ft})$ to the northwest (DOE, 1996).

H-Area is also located on a near-surface groundwater divide between Upper Three Runs and Fourmile Branch. The near-surface groundwater from the northern part of the H-Area Tank Farm discharges to Upper Three Runs, approximately $1,219 \mathrm{~m}(4,000 \mathrm{ft})$ to $3,658 \mathrm{~m}$ $(12,000 \mathrm{f})$ north to northeast of the tank farm. The near-surface groundwater from the southern part of the H-Area Tank Farm discharges to Fourmile Branch, approximately $1,524 \mathrm{~m}(5,000 \mathrm{ft})$ to $4,572 \mathrm{~m}(15,000 \mathrm{ft})$ southwest of the tank farm (DOE, 1996).

\subsection{Ecological and Cultural Resources}

Since 1951, when the U.S. Government acquired SRS, natural resource management practices and natural succession outside of the construction and operation areas at SRS 


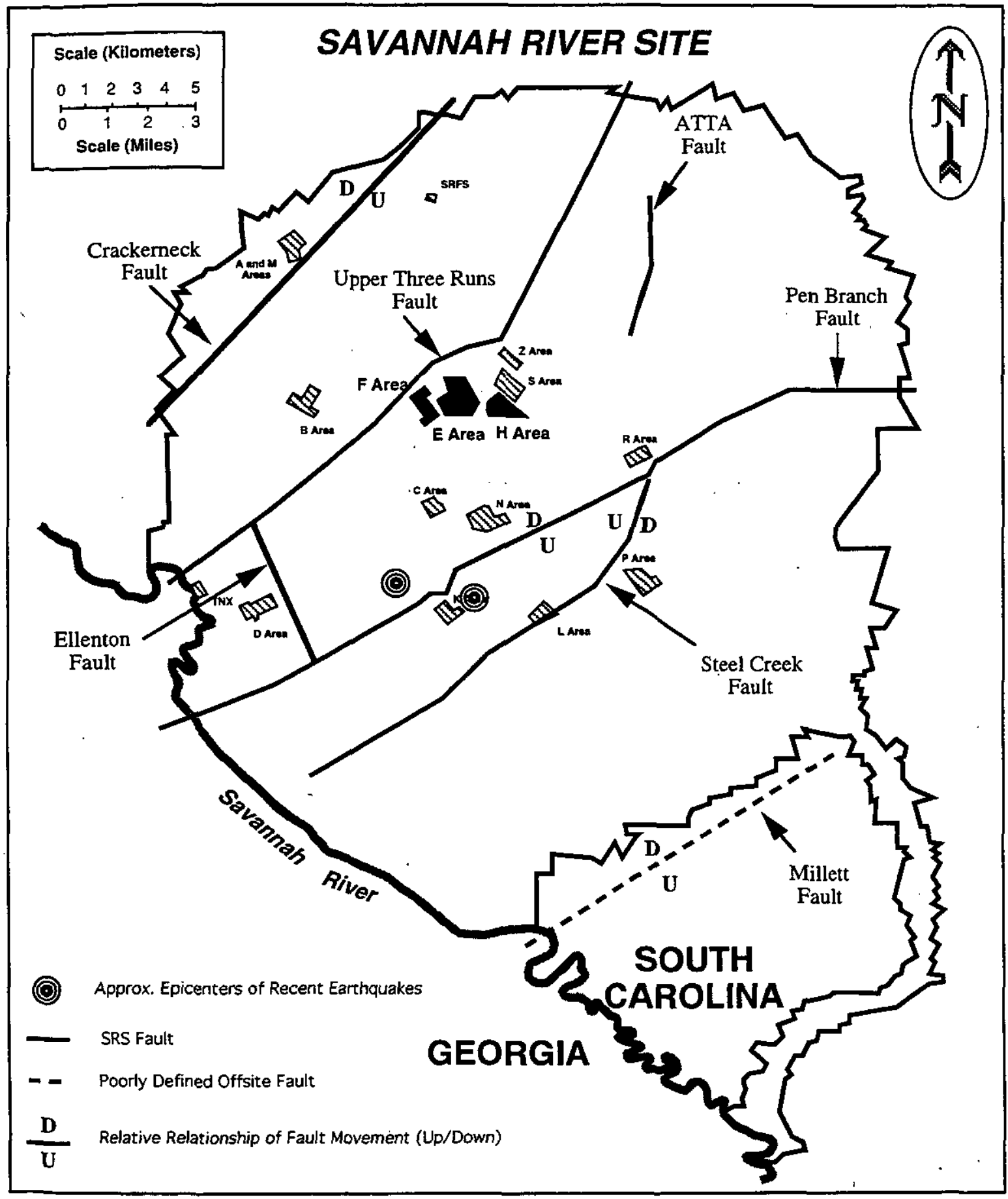

Figure 3-1. Location of seismic faults at the Savannah River Site, South Carolina. 
have resulted in increased ecological complexity and diversity of the site. Forested areas support a diversity of wildlife habitats that are restricted from public use. Forest management practices include controlled burning, harvesting of mature trees, and reforesting. Wildlife management includes control of SRS white-tailed deer (Odocoileous virginianus) and wild swine (Sus scrofa) populations through supervised hunts. SRS, which was designated as the first National Environmental Research Park in 1972, is one of the most extensively-studied environments in this country. Wike et al. (1994) contains additional information on the biotic characteristics of SRS.

Six species on SRS are afforded protection by the Federal government under the Endangered Species Act of 1973. They are the bald eagle (Haliaeetus leucocephalus), wood stork (Mycteria americana), red-cockaded woodpecker (Picoides borealis), American alligator (Alligator mississippiensis), shortnose sturgeon (Acipenser brevirostrum), and smooth purple coneflower (Echinacea laevigata).

Due to the industrial nature of the tank farms, the activities and the plants or animals mentioned do not exist within the boundaries of the fenced portion where the activities associated with the closure of the tanks would take place.

A Memorandum of Agreement (MOA), ratified on August 24, 1990, exists for the management of cultural resources at SRS. DOE uses this (MOA) to identify cultural resources, assess them in terms of eligibility for the National Register of Historic Places, and develop mitigation plans for affected resources in consultation with the State Historic Preservation Officer (DOE, 1996).

Studies of F- and H-Areas in a previous EIS (DOE, 1994) noted that activities associated with the construction of F- and H-Areas during the 1950 s could have destroyed historic and archaeological resources present in this area. If any historic or archaeological resources are threatened by HLW tanks closure activities under this plan, appropriate steps would be taken to identify the resource found and to contact the appropriate agency in accordance with the MOA (DOE, 1996).

\subsection{Radiation Environment}

A person residing in the Central Savannah River Area (within $80 \mathrm{~km}$ (50 mi) of SRS) receives an average annual radiation dose of about $360 \mathrm{mrem}$. Natural radiation sources contribute about 295 mrem, medical exposures contribute about $53 \mathrm{mrem}$, and consumer products contribute about 10 mrem. SRS contributes 0.23 mrem (less than 0.1 percent of that total). The most recent SRS annual environmental report (Arnett et al., 1995) contains more information on the radiation environment at SRS.

\subsection{ENVIRONMENTAL CONSEQUENCES OF THE PROPOSED ACTION AND ALTERNATIVES}

\subsection{Tank System Closure}

For all closure alternatives, direct and indirect socioeconomic impacts of the proposed tank closure construction workforce would be negligible when compared to the present total SRS employment of approximately 14,000 people. All of the construction workforce would likely be derived from the existing ranks of local construction companies. Therefore, no measurable impact on the local economy would be expected from the proposed action. Because no socioeconomic impacts are expected as a result of the 
proposed action, no disproportionate impacts on minority or low income communities would result.

The construction activities for each of the closure alternatives may include, as applicable, the removal of pipes, equipment, electrical conduit and wires, lead loosely wrapped around pipes for shielding, evaporators, and other miscellaneous parts necessary to complete the closure process. It is estimated that approximately $85 \mathrm{~m}^{3}\left(3,000 \mathrm{ft}^{3}\right)$ of equipment above the ground surface could be removed, placed in B-25 (radioactive waste storage container) boxes or equivalent, and transported to the E-Area vaults for long term disposal. A B-25 box holds approximately $2.55 \mathrm{~m}^{3}\left(90 \mathrm{ft}^{3}\right)$ of material. It can be assumed that a box would contain $1 / 5$ of $2.55 \mathrm{~m}^{3}\left(90 \mathrm{ft}^{3}\right)$ of the cut up equipment which could result in as many as $167 \mathrm{~B}-25$ boxes per tank if all the surface equipment were removed (DOE, 1996; Hall, 1996).

For closure alternatives involving fill, other construction activities would include the installation of the transfer pipes to be used in pumping the fill mixture to the tanks. The piping would be changed and rerouted to other tanks as each tank is filled.

The construction workers would receive some radiation exposure during the removal process and while stabilizing the tanks with fill. All workers would wear proper personnel protective equipment as specified by the radiation control program and would maintain their radiation exposure as low as reasonably achievable. Exposure levels to workers could be expected to be on the order of 10 to 11 man-rem per tank averaged over 37 workers, or about 0.3 rem per worker per year. This was derived by breaking the tank closure down into four parts and adding the total exposures together. The first phase is the removal of the surface structure which incorporates ten workers for twelve weeks in a one mrem $/ \mathrm{hr}$ field that equals 4800 mrem. This equates to 4.8 man rem. The second phase is installing a portable pumping station and running the piping to the tanks which utilizes five workers for twelve weeks in a $0.5 \mathrm{mrem} / \mathrm{hr}$ field. This equates to $1.2 \mathrm{man}$ rem. The third phase is the filling of the tanks with the backfill material utilizing eleven workers for 20 weeks in a $0.5 \mathrm{mrem} / \mathrm{hr}$ field. This equates to $4.4 \mathrm{man} \mathrm{rem}$. The final phase, if required, is installing the cap on the tanks which employs eleven workers for four weeks in a $0.1 \mathrm{mrem} / \mathrm{hr}$ field which equates to 0.2 man rem (Hall, 1996). This estimated exposure of about 0.3 rem per worker per year is less than the current SRS administrative limit of 0.8 rem per year.

Since the area of the proposed action has been within a developed industrialized area for the last 50 years, no adverse impacts to known cultural or biotic (e.g., threatened and endangered species) resources would be expected to result from the construction activities. Neither wetlands nor floodplains exist within or adjacent to the project area.

Air quality effects associated with the tank closure activities would fall within two areas: equipment use and soil disturbance. Diesel operated equipment (i.e., trucks, backhoes, and other diesel powered support equipment) would be used for material to fill the tanks, to haul soil and other debris for disposal, for excavation, capping activities, if required, and in the performance of other routine construction activities. The operation of this type of equipment does not require an air quality permit from SCDHEC. If a batch plant were used on site to mix fill material, some fugitive dust would be produced.

\subsection{Post-Tank Closure}

When the F- and H-Tanks are closed, there will be minimal active operational and maintenance activities in the area. The major impacts anticipated during post-tank closure would be the release of contamination from the closed tanks due to deterioration of the 
tanks in future years. This contamination is expected to migrate, over a period of several thousand years, into the groundwater and eventually, via the seepline, to Upper Three Runs and Fourmile Branch. By the time the contamination reaches the seepline (which is defined as the point of compliance in the Closure Plan) of the creeks, the contamination levels would fall within the acceptable stream standard limits. A detailed discussion of the tank closure performance evaluation and performance objectives are presented in the Closure Plan (DOE, 1996).

\subsection{Human Health Effects}

The accident analyses and fate and transport modeling (DOE, 1996) indicate that after closure, there are no airbome releases that would result in any human health effects. As the HLW tanks are underground, runoff or surface soil contamination is not expected.

The contaminated zone would be encountered below the surrounding, original land surface, therefore, groundwater is where the contamination is anticipated to occur. Human receptors will potentially be exposed to contaminants through various pathways associated with the surface water adjacent to the seepline where the contaminated groundwater reaches the surface.

As an example of the impacts that might occur, fate and transport modeling, using various post-closure tank configurations, was performed using Tanks 17 through 20 in the F-Area Tank Farm (DOE, 1996). The specific closure scenarios modeled were: (1) bulk waste removal and spray wash, no fill material (no action), (2) bulk waste removal and spray wash, fill tanks with pumpable backfill material, (3) bulk waste removal and spray wash, fill tanks with pumpable backfill material, place an engineered cap over filled tanks, and (4) bulk waste removal and spray wash, fill tanks with sand, and place an engineered cap over filled tanks.

The modeling assumed institutional control for 100 years and subsequent industrial land use. The area immediately around the F-Area Tank Farm would remain in commercial/industrial use for the entire 10,000-year period of analysis. The area of commercial/industrial land use would extend to Fourmile Branch in the direction of groundwater flow in the unconfined aquifer. The modeling estimated the potential human health and ecological impacts of residual contamination remaining in closed HLW tanks. The modeling also estimated the concentration and dose levels at the groundwater seepline, which is the established point of compliance.

Radiological doses at the seepline (the point of compliance) were calculated to be as high as $5 \mathrm{mrem} /$ year (Scenario 1 - No Action) and as low as $3.4 \mathrm{mrem} / \mathrm{year}$ (Scenario 3 - Backfilled with Cap). The acceptable limit is 4.0 mrem per year. Essentially all of this dose is due to selenium-79 and technetium (Tc-99) because the other radionuclides either decay en route or do not migrate at a sufficient rate to reach the seepline. The calculated gross alpha concentration at the seepline demonstrates that appreciable amounts of plutonium-239 do not arrive at the seepline within the 10,000 year period of analysis, regardless of the analyzed scenario. The lifetime risk of incidence of excess cancer for the most affected human receptor was calculated to be in the order of $1.8 \mathrm{E}-07$ or less for all scenarios.

For nonradiological constituents a full tank was used for the analysis. Nitrate is the only contaminant to reach the seepline in quantities that could exceed the maximum contaminant level. After bulk waste removal plus spray washing, values would be lowered to a point where maximum contaminant levels would not be exceeded (DOE, 1996). 
The modeling shows that maximum doses and concentrations of contaminants do not vary dramatically between closure alternatives (usually by less than an order of magnitude). The primary difference is in the arrival time of the maximum dose/concentration at the seepline several thousand years after closure.

For any tank closure module, SCDHEC limits would not be exceeded at the seepline of Fourmile Branch and Upper Three Runs, thus significant human health effects are not expected from surface water contamination from the proposed action.

\subsection{Transportation Impact Analysis}

SRS is served by more than $320 \mathrm{~km}(199 \mathrm{mi})$ of primary roads and more than $1600 \mathrm{~km}$ ( $995 \mathrm{mi}$ ) of unpaved secondary roads. The primary highways used by SRS commuters are State Routes 19,64, and 125; 40, 10, and 50 percent of the workers use these routes respectively. Significant congestion can occur during peak traffic periods onsite on SRS Road 1-A, State Routes 19 and 125, and U.S. Route 278 at SRS access points. These same routes and access points would be used by construction vehicles associated with this action.

Action to fill any tank would require materials such as sand, cement, flyash, and blast furnace slag to be transported to the site to make the fill material. The trucks could come to the site with premixed fill material batched at the vendor's facility. Approximately 800 to 900 truck loads of material would be required to fill each waste tank (DOE, 1996). This would require 800 to 900 round trips from an offsite vendor's facility for each tank or a total of approximately 45,900 round trips. Assuming that the material is supplied by vendor facilities in Jackson and New Ellenton, closure of the tanks would result in approximately 2.3 million miles traveled during the waste tank closure process. Using U.S. Department of Transportation national average accident rate data for fatalities and injuries (DOT, 1982), the proposed transportation activity would result in 0.01 additional fatalities and 0.79 additional injuries.

The transportation impacts for tank removal would be less than any fill alternative as only 780 truck loads are required and all movement would be on site.

Regardless of alternative chosen, it is anticipated that one tank would be closed at a time, thus, the existing transportation structure would be adequate to accommodate this projected traffic volume. None of the routes associated with this transportation would require additional traffic controls and/or highway modifications. The surrounding area already has a certain volume of truck and car traffic associated with SRS logging, agriculture, and industrial activity. The amount of traffic associated with the proposed action is minimal.

\subsection{Accident Impact Analysis}

To assess the impact of accidents associated with the proposed action, it was necessary to perform a comparative analysis of pre-closure HLW tank operations and post-closure conditions. This analysis, provided in Appendix $\mathrm{C}$, examined the most severe potential accidents associated with the HLW tank farm operations and determined the impact those same accidents would have on the waste tanks after closure.

None of the 13 design basis accidents for current tank farm operation involves a significant airborne release of radioactive material. Only the tornado scenario would result in a release of vapors from a waste tank under current operating conditions. After closure of the waste tanks, there would be no vapor space in the tanks and, thus, no vapors present in the waste tanks, and no unsealed waste tank penetrations. Therefore, a tornado would not result in 
any release from the closed waste tanks. Based on this review of the current accident analyses, there are no credible accident airborne release mechanisms for the HLW tanks after tank closure.

\subsection{Environmental Consequences of the Alternatives}

No direct environmental impacts are expected as the proposed action will take place within a previously-developed industrial area. However, the near surface groundwater (measured at 1-meter and 100-meters down gradient from the tank farms) is expected to become contaminated such that it will not meet SCDHEC standards. This is not expected to occur until several hundred years after tank closure when the tank, grout, and basemat are anticipated to fail due to deterioration, as indicated by the fate and transport modeling performed for the Closure Plan (DOE, 1996).

The mobile contaminants in the tanks will gradually migrate downward through the soil to the groundwater aquifer. The contaminants will be transported by the groundwater to the seepline and subsequently to either Fourmile Branch or Upper Three Runs. As indicated by the fate and transport modeling (DOE, 1996), the contaminants in the groundwater are expected to be reduced, such that, by the time they reach the seepline of the creeks they would be within the acceptable limits. Upon reaching the surface water, some contaminants will possibly contaminate the seepline, sediments at the bottom of Fourmile Branch and Upper Three Runs, and the shoreline, but would be at levels below regulatory concerns. Aquatic organisms in the-stream and plants along the shoreline will become exposed to the contaminants. Terrestrial organisms may then ingest the contaminated vegetation and also obtain their drinking water from the contaminated stream.

The modeling shows that maximum doses and concentrations of contaminants do not vary dramatically between closure alternatives (usually by less than an order of magnitude). The primary difference is in the arrival time of the maximum dose/concentration at the seepline several thousand years after closure.

\subsection{Cumulative Impacts}

There would be no measurable increase in the local economy as a result of the proposed action and thus no cumulative impacts are anticipated.

The site usage of domestic and potable water would be increased by less than one percent. The volume of sanitary wastewater treated at the Central Treatment Facility would increase by less than one percent.

The cumulative impact on the site streams are caused by the combination of this action's HLW contaminants and the other contaminant plumes which eventually enter Upper Three Runs to the west of the tank farms and Fourmile Branch to the south. Groundwater transport segments (GTS) will be defined for the tanks to be closed to apportion the performance objectives to the target tank system(s) and other sources of contaminants that may impact the same point of exposure. A GTS represents the adjacent contaminant plume from the tank system(s) considered for closure and all other sources within the segment. In general, a GTS will run from the groundwater divide to the point of exposure. The performance objectives established in the Closure Plan (DOE, 1996) limit these to acceptable levels.

Currently, construction activities on site are winding down and workforce restructuring is decreasing the amount of vehicle traffic associated with activities at the site. However, increased truck traffic would be caused by the construction and operation of the Three 
Rivers Solid Waste Authority Regional Waste Management Center discussed in Environmental Assessment DOE/EA-1079 (DOE, 1995b). This tank closure action only adds 10 to 40 trucks per day.

\subsection{REGULATORY AND PERMITTING. PROVISION CONSIDERATIONS}

\subsection{National Environmental Policy Act of 1969, as Amended (42 USC 4321 et seq.)}

This EA has been prepared in compliance with the NEPA of 1969, as amended, and the Council on Environmental Quality Regulations for Implementing NEPA (40 CFR Parts 1500-1508), DOE Regulations (10 CFR Part 1021), and DOE Order 451.1. NEPA, as amended, requires "all agencies of the Federal Government" to prepare a detailed statement on the potential environment effects of proposed "major Federal actions significantly affecting the quality of the human environment." This EA has been prepared to comply with NEPA and to assess the significance of the environmental effects of closing the 51 HLW storage tanks in F- and H-Areas.

\subsection{Federal Facility Agreement (FFA)}

A FFA (DOE, EPA, and SCDHEC, 1993) was executed by DOE, EPA, and SCDHEC, and became effective on August 16,1993. The FFA provides standards for secondary containment, requirements for responding to leaks, and provisions for the removal from service of leaking or unsuitable HLW storage tanks. Tanks that do not meet the standards set by the FFA may be used for the continued storage of their current waste inventories, but these tanks are required to be placed on a schedule for removal from service. The "F/H Area High-Level Waste Removal Plan and Schedule," submitted to EPA and SCDHEC on November 10,1993, shows specific start and end dates for the removal from service of each non-compliant tank, and commits SRS to remove the last non-compliant tank from service no later than 2028.

The FFA requires that the tanks be closed under the requirements of the Pollution Control Act via the tank farm industrial wastewater permits. Subsequent to wastewater closure, the FFA requires an additional evaluation under the RCRA/CERCLA sections of the agreement. However, after negotiations between the three parties, the FFA may be modified to reflect an integrated approach to tank systems closure.

\subsection{Industrial Wastewater}

The FFA (DOE, EPA, and SCDHEC, 1993) directed SRS to submit an industrial wastewater permit application to SCDHEC. Upon issuance of the permit to operate on March 3, 1993, SRS requested the withdrawal of the tank farms from the Site RCRA Part A permit application. The tank farms currently operate under Industrial Wastewater Permit to Operate \#17-424-1W, \#14338, and \#14502. This permit allows for the continued operation of the tank farms as described in Appendix A. The permit regulates the removal of waste from all $51 \mathrm{HLW}$ tanks as well as the pretreatment of the waste in the ESP and ITP facilities. SRS is driven to empty these tanks through the FFA via the wastewater permit. After removal of non-compliant tanks from service, the tanks will be closed as described in the Closure Plan (DOE, 1996). 


\subsection{Additional Regulatory And Permitting Provisions}

DOE has identified all applicable or relevant and appropriate environmental requirements and guidance it will comply with and consider, respectively, to insure that the tank system closures will be protective of human health and the environment and are consistent with final corrective/remedial action as implemented under the FAA. Details of these can be found in Chapter 5 of the Closure Plan (DOE, 1996). 


\subsection{REFERENCES}

Arnett, M. W., D. Spitzer, and A. R. Mamatey, 1995. Savannah River Site Environmental Report for 1994, WSRC-TR-95-075, Westinghouse Savannah River Company, Savannah River Site, Aiken, South Carolina.

DOE (Department of Energy), 1982. Environmental Assessment, Waste Form Selection For SRP High-Level Waste, DOE/EA-00179, Savannah River Site, Aiken, South Carolina.

DOE (Department of Energy), 1994. Final Supplemental Environmental Impact Statement, Defense Waste Processing Facility. DOE/EIS-0082-S, Savannah River Operations Office, Savannah River Site, Aiken, South Carolina.

DOE (Department of Energy), 1995a. Final Environmental Impact Statement Waste Management, DOE/EIS-0217, 1995, Savannah River Site, Aiken, South Carolina.

DOE (Department of Energy), 1995b. Environmental Assessment, Construction and Operation of the Three Rivers Solid Waste Authority Regional Waste Management Center, DOE/EA-1079, Savannah River Site, Aiken, South Carolina.

DOE (Department of Energy), 1996. Industrial Wastewater Closure Plan for F- and H-Area High-Level Waste Tanks, Preliminary Draft, May 15, 1996, Savannah River Operations Office, Savannah River Site, Aiken, South Carolina.

DOE, EPA, and SCDHEC (Department of Energy, Environmental Protection Agency, and South Carolina Department of Health and Environmental Control), 1993. Federal Facility Agreement for the Savannah River Site, Administrative Docket No. 89-05-FF, signed January 15, 1993, effective August 16, 1993, Department of Energy, Savannah River Operations Office, Aiken, South Carolina.

DOT (Department of Transportation), 1982. Large Truck Accident Causation, DOT-HS-806300, National Highway Traffic Safety Administration, Washington, DC.

du Pont (E.I. du Pont de Nemours and Company, Inc.), 1980. Tank 16 Demonstration, Water Wash and Chemical Cleaning Results, DPSP 80-17-23, Savannah River Site, Aiken, South Carolina.

du Pont (E.I. du Pont de Nemours and Company, Inc.), 1982. Decommissioning Alternative for Waste Tank 16, DPST-82-456, Savannah River Laboratory, Aiken, South Carolina.

Hall, S. M., 1996. Interoffice Memorandum to M. L. Hess, Info Requested For HLW EA, HLW-HLE-96-0225, May 1, 1996, Westinghouse Savannah River Company, Aiken, South Carolina.

NUS (Halliburton NUS Environmental Corporation), 1992. Socioeconomic Characteristics of Selected Counties and Communities Adjacent to the Savannah River Site, Halliburton NUS Corporation, Aiken, South Carolina. 
Parsons, A. M.and M. M Gruebel, 1996. Hydrogeology of the F-Area at the Savannah River Site, Rev. 0, Sandia National Laboratories, Albuquerque, New Mexico.

SCDHEC (South Carolina Department of Health and Environmental Control), 1993. Construction Permit \#17,424-IW, "SRS F/H-Area", 25 January 1993, transmitted by Marion F. Sadler, Jr.

Wike, L. D., R. W. Shipley, A. L. Bryan, Jr., J. A. Bowers, C. L. Cummins, B. R. del Carmen, G. P. Friday, J. E. Irwin, J. J. Mayer, E. A. Nelson, M. H. Paller, V. A. Rogers, W. L. Specht, and E. W. Wilde, 1994. SRS Ecology: Environmental Information Document, WSRC-TR-93-496, Westinghouse Savannah River Company; Savannah River Site, Aiken, South Carolina.

WSRC (Westinghouse Savannah River Company), 1989. Reactor Operation Environmental Information Document. Volume III: Meteorology, Surface Hydrology, Transport and Impacts (U), WSRC-RP-89-817, Westinghouse Savannah River Company, Aiken, South Carolina.

WSRC (Westinghouse Savannah River Company), 1991. Baseline Risk Assessment For The F- and H-Area Seepage Basins Groundwater Unit, Draft Final, WSRC-RP-91-950, Westinghouse Savannah River Company, Aiken, South Carolina.

WSRC (Westinghouse Savannah River Company), 1995a. High Level Waste Engineering Monthly Data Report (U), WSRC-RP-95-841-7, Westinghouse Savannah River Company, Aiken, South Carolina.

WSRC (Westinghouse Savannah River Company), 1995b. Annual Radioactive Waste Tank Inspection Program - 1994 (U), WSRC-TR-95-166, Westinghouse Savannah River Company, Aiken, South Carolina.

WSRC (Westinghouse Savannah River Company), 1995c. Safety Analysis Report Savannah River Site, WSRC-SA-19, Rev. 0, Westinghouse Savannah River Company, Aiken, South Carolina. 


\section{Appendix A}

\section{HIGH LEVEL WASTE SYSTEM DESCRIPTION}

The F- and H-Area High Level Waste (HLW) Tank Farms are located in the central portion of the Savannah River Site (SRS). The tank farm sites were chosen because of their favorable terrain, close proximity to the F- and H-Area Separations Facilities (the major waste generating sources), and large isolation distance (minimum distance is approximately $8.9 \mathrm{~km}, 5.5 \mathrm{mi}$ ) from the SRS boundaries.

The F-Area HLW Tank Farm is located on a 9 ha (22-acre) site and consists of 22 waste tanks, two evaporator systems, transfer pipelines, six diversion boxes, and three pump pits.

The H-Area HLW Tank Farm is located on a 18 ha (45-acre) site and consists of 29 waste tanks, two evaporator systems, the In-Tank Precipitation (ITP) process building and associated equipment, transfer pipelines, eight diversion boxes, and ten pump pits.

As depicted in Figure A-1, the F- and H-Area HLW Tank Farms were constructed to:

- Receive radioactive wastewaters generated by the various SRS production, process, and laboratory facilities

- Isolate the radioactive wastes from the environment; plant workers, and general public

- Allow radioactive decay by aging the wastewater

- Provide wastewater clarification by gravity settling in waste tanks

- Remove soluble salts from the wastewater by evaporation and/or ion exchange

- Pretreat the accumulated sludge and salt solutions to allow management of these wastes at other wastewater treatment facilities (i.e., Defence Waste Processing Facility (DWPF) and Z-Area Saltstone Manufacturing and Disposal Facility) for conversion to more stable forms and placement in permanent disposal facilities

To accomplish the above objectives, the tank farms contain 51 large underground waste tanks to receive and age the waste streams, four evaporator systems (Two are currently operational and a fifth evaporator system is currently under construction) to remove soluble salts, a precipitation/filtration system (i.e., ITP facility) to pretreat the salt solutions, a sludge washing system (i.e., Extended Sludge Processing) to pretreat the accumulated sludge, and a transfer system to transfer the wastes.

All of the tanks were built of carbon steel inside reinforced concrete containment vaults, but were built with four different designs. Two designs (Types I and II,) have five foot high secondary annulus "pans" and forced cooling. There were twelve Type I Tanks (Figure A-2) built (Tanks $1-12$ ) between 1951 and 1954. Five tanks (Tanks 1, 9 - 12) have leaked detectable amounts of waste from primary to secondary containment. The tank tops are about $2.9 \mathrm{~m}(9.5 \mathrm{ft})$ below grade. The bottoms of the tanks are situated above the seasonal high water table. Tanks 9 - 12 are located in the H-Area Tank Farm and are in the water table. 


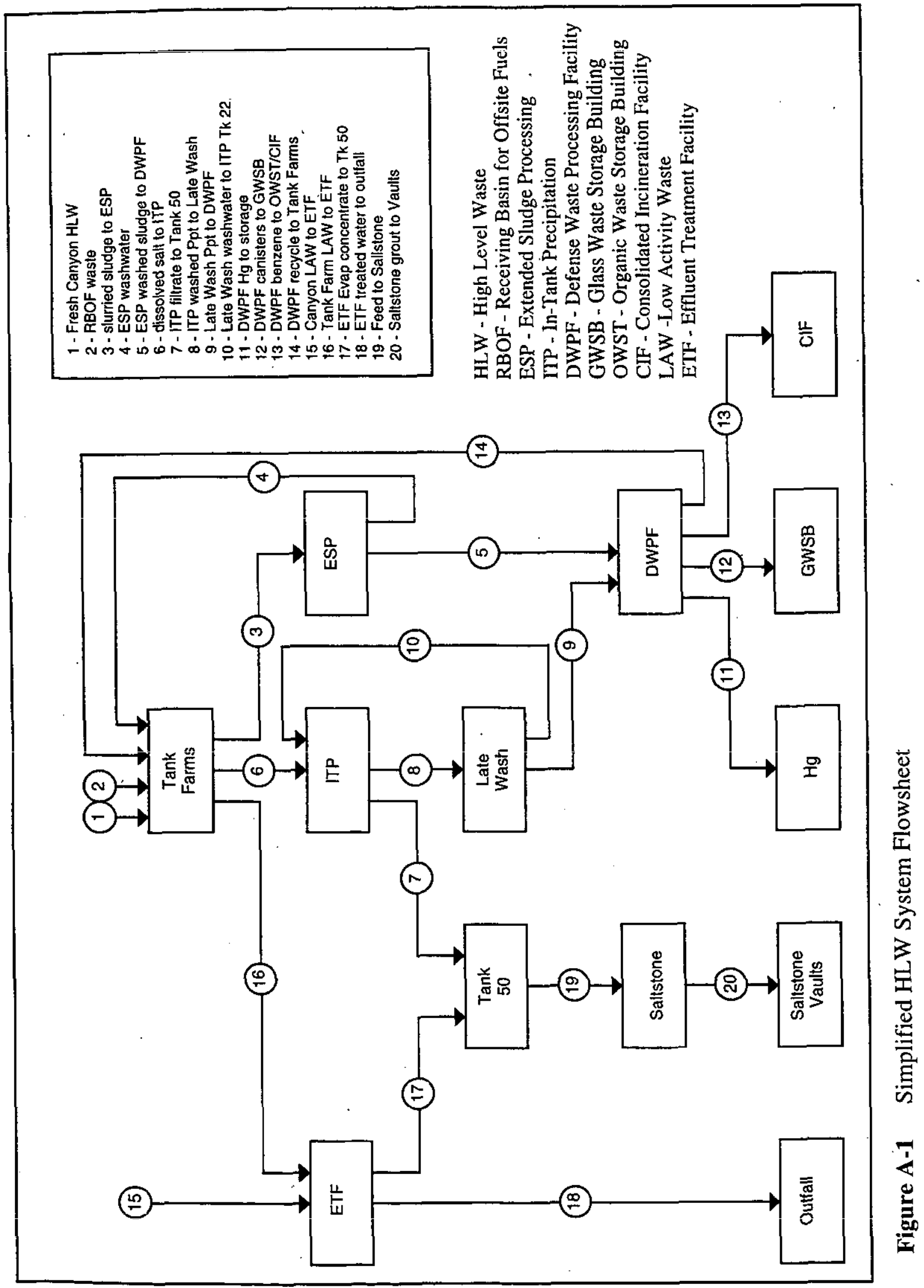




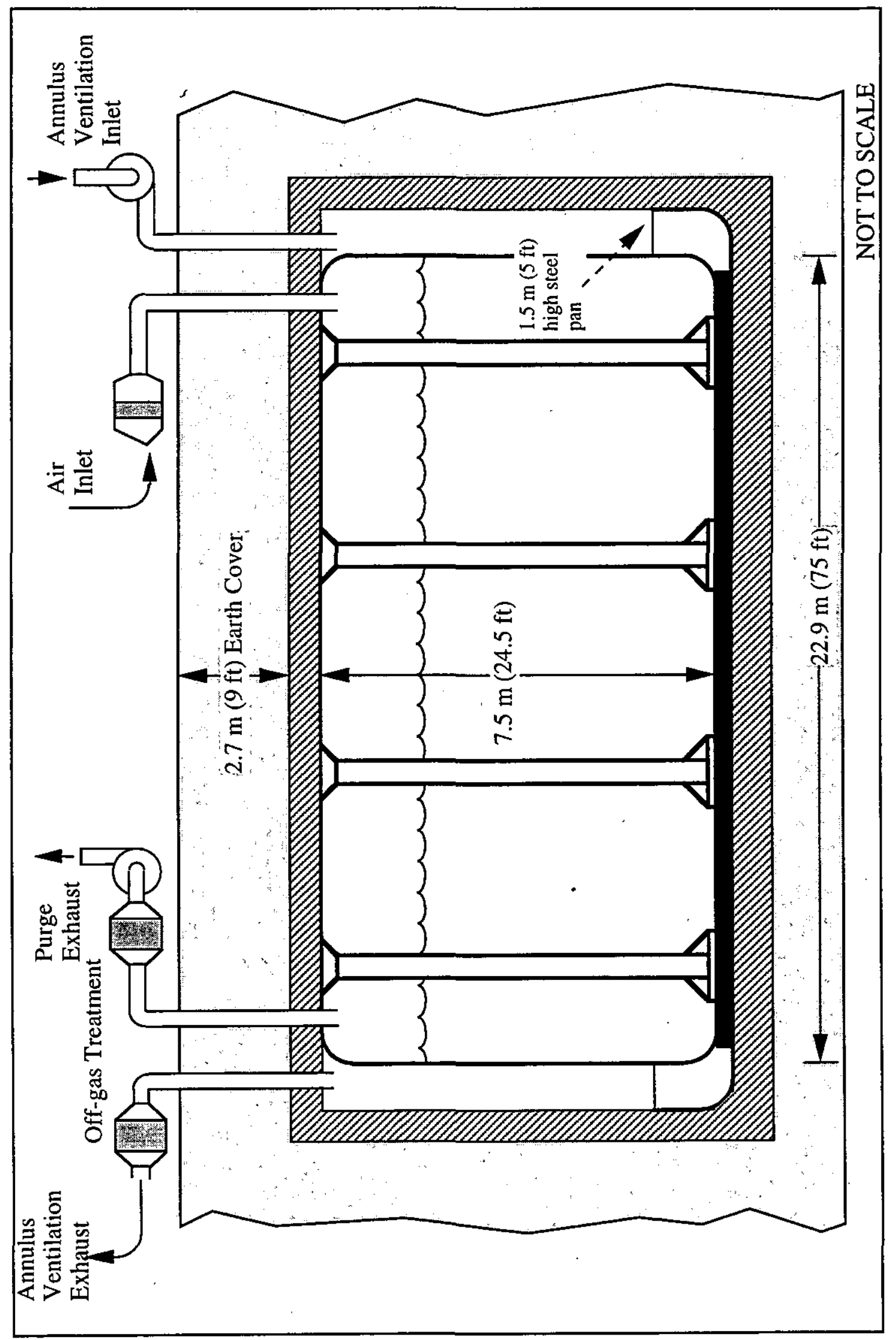

 
There were four Type II Tanks (Tanks 13 - 16) (Figure A-3) built between 1961 and 1964 and are all located in the H-Area Tank Farm. All four have leaked detectable amounts of waste from primary to secondary containment. On one tank, Tank 16 , a small amount of waste overflowed the annulus pan and leaked into the surrounding soil. Waste removal from the Tank 16 primary vessel was completed in 1980 . The waste that leaked into the annulus has not been removed. These tanks are situated above the seasonal high water table.

The newest design, Type III (Figure A-4), has a full-height secondary tank and forced water cooling. All of the Type III Tanks (Tanks 25 - 51) were situated above the water table. These tanks were placed in service between 1972 and 1981 . None of these tanks have known leak sites.

The fourth design, Type IV (Figure A-5), has a single steel wall and does not have forced cooling. There were eight Type IV Tanks (Tanks 17 - 24) built between 1958 and 1962. Tanks $17-20$ are located in the F-Area Tank Farm and Tanks $21-24$ are located in H-Area. Tanks 19 and 20 have known leak sites that are believed to have been caused by groundwater corrosion of the tank wall. Small amounts of groundwater have leaked into these tanks; there is no evidence that waste has leaked out. Tanks $17-20$ are slightly above the water table. Tanks 21 - 24 are above the groundwater table. However, they'are in a perched water table caused by the original basemat under the tank area.

The influent wastewaters are classified as high-level radioactive wastes (HLWs). HLWs are produced during the reprocessing of spent nuclear fuel or are derived from other processes which handle HLWs. The HLWs emit harmful levels of radiation and must be isolated to prevent employee exposure to radiation; therefore, direct inspection maintenance of process equipment is not normally conducted. The process equipment is shielded with lead, soil, concrete or steel. Maintenance is normally conducted remotely to prevent exposure of personnel to radiation sources. Should hands-on maintenance be required, the piece of process equipment must be isolated from sources and decontaminated.

The waste treatment activities conducted at the F- and H-Area HLW Tank Farms are "closed-loop" processes which do not have any direct aqueous discharges to the environment. All of the effluent waste streams produced by the tank farms are transferred to other SRS facilities for further treatment. The treatment activities conducted at the F and H-Area HLW Tank Farms are briefly described below.

\section{Waste Receipt and Aging}

The freshly generated HLW is further classified as either High-Heat Waste (HHW) or Low-Heat Waste (LHW). HHW is generated during the first solvent extraction of the spent nuclear fuel. LHW is generated from the second and subsequent solvent extractions of the spent nuclear fuel and other support. The freshly generated HHW and LHW are segregated to improve processing of the residual sludge and salt solutions within the Tank Farms and DWPF Vitrification Facility.

HHW contains most of the radionuclides and must be aged in a receipt tank to permit radioactive decay of the short-lived radioisotopes (i.e., half-life is less than 90 days) prior to further processing. The thermal energy resulting from radioactive decay of these short-lived radioisotopes requires supplemental cooling (i.e., cooling coils) to maintain the temperature of the HHW receipt tank within operating guidelines. When the radioactivity of HHW in the receipt tank has decayed sufficiently, the liquid supernate is decanted 


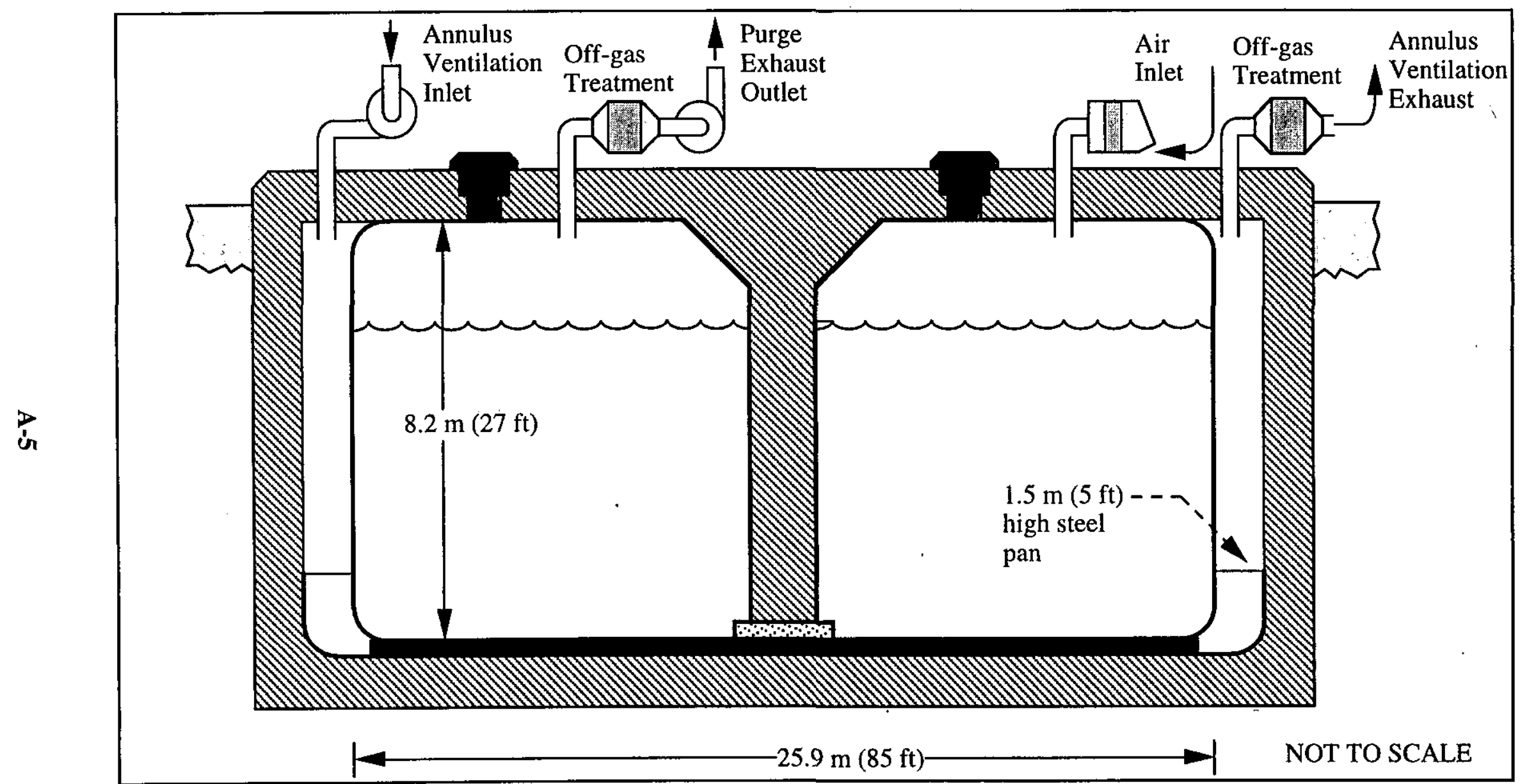

Figure A-3. Type II Waste Tank--3,898,974 I (1,030,000 gal) capacity 


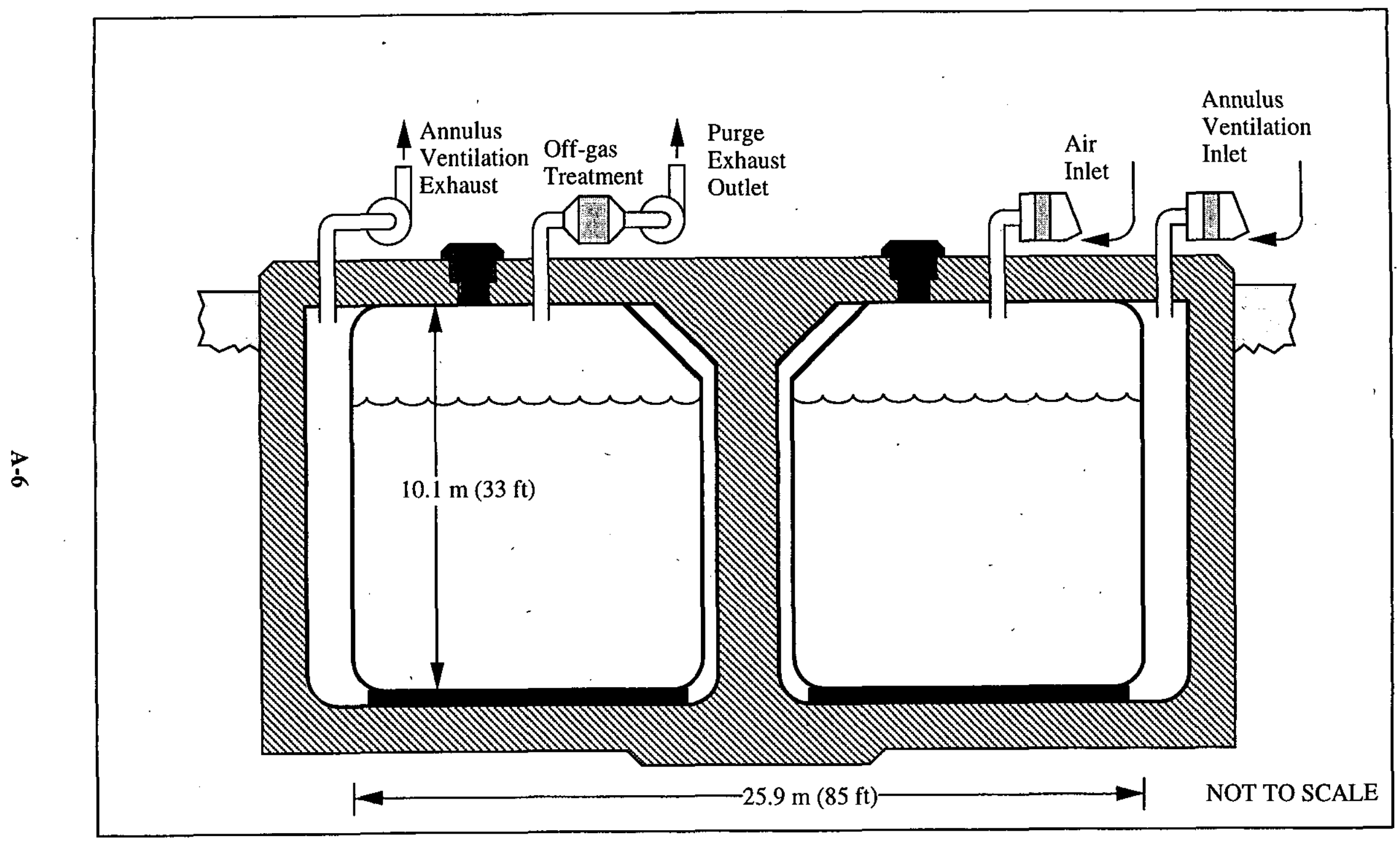

Figure A-4. Type III Waste Tank--4,921,035 I (1,300,000 gal) capacity 


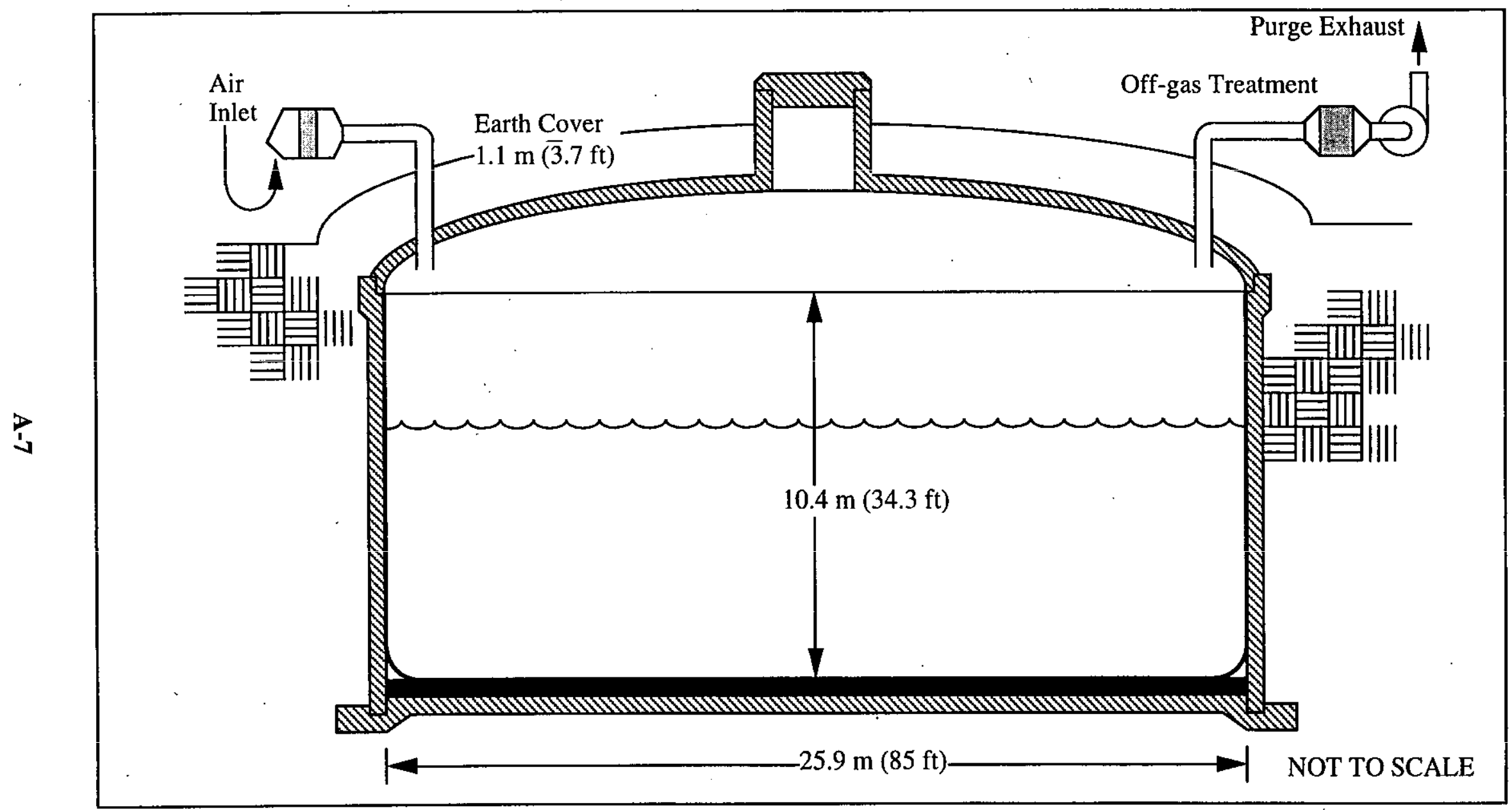

Figure A-5. Type IV Waste Tank--4,921,035 1 (1,300,000 gal) capacity 
and transferred to a HHW evaporator feed tank for subsequent removal of the dissolved solids through evaporation.

The freshly generated LHW contains a lower concentration of radionuclides; as a result, the LHW normally does not require aging and supplemental cooling prior to evaporation. This LHW is normally received directly in a LHW evaporator feed tank for subsequent removal of the dissolved solids through evaporation of the liquids.

\section{Waste Evaporation}

HHW and LHW supemates are transferred from the evaporator feed tanks and heated to the aqueous boiling point in an evaporator. HHW and LHW are normally processed through segregated evaporator systems. The evaporated liquids (overheads) are condensed and, if required, processed through an ion exchange column for cesium removal. The overheads are then transferred to the F/H Effluent Treatment Facility for final treatment prior to being discharged to Upper Three Runs. The evaporator overheads may also be recycled back to a waste tank should evaporator process upsets occur.

\section{Salt Cake Processing}

HHW and LHW waste streams contain dissolved salts which are removed through evaporation of the liquids. The concentrated wastes from the evaporators (evaporator bottoms) are sent to a waste concentrate receipt tank with supplemental cooling. Supplemental cooling is required for the evaporator bottoms to remove the heat which is added during evaporation. As the hot concentrated waste cools, a solid salt cake forms and is deposited within the waste concentrate receipt tank. The supernate remaining in the waste concentrate receipt tank is returned to an evaporator feed tank for further processing. Over time, the waste concentrate receipt tank fills with salt cake. Aging of this salt is also required since the radionuclides are concentrated by the evaporation process.

Starting in 1981, HHW and LHW evaporator bottoms have been segregated into separate waste concentrate receipt tanks. Prior to 1981, HHW and LHW evaporator bottoms were combined in the same waste concentrate receipt tank. The combined HHW/LHW salt cakes are managed as a HHW salt cake.

HHW and LHW salt cakes undergo another aging period of several years before radioactive/chemical decontamination may proceed. The aged HHW and LHW salt cakes are dissolved and transferred in batches to the ITP reaction vessel. The dissolved HHW and LHW salt cakes (called salt solution) are combined with each other to achieve blending of the radionuclides and other chemical compounds. This blending is performed to provide more consistent waste feed to the ITP process and subsequent waste feed to the Z-Area Saltstone Manufacturing and Disposal Facility (SMDF) and DWPF Vitrification Facility. The combined salt solution is treated with chemical compounds to precipitate and adsorb a majority of the radionuclides. The resulting slurry is filtered within the ITP filter building. The filtrate (called decontaminated salt solution) is transferred to Tank 50 . The decontaminated salt solution is combined with the concentrate reject from the F/H ETF and transferred to the Z-Area SMDF for solidification and on-site disposal. The remaining precipitate slurry undergoes a washing step to remove residual soluble salts and process chemicals prior to being transferred to the DWPF Vitrification Facility for vitrification into a solid glass matrix for disposal. 


\section{Sludge Processing}

The HHW and LHW waste streams generated by the F- and H-Area Separations Facilities contain insoluble and highly radioactive metal hydroxides (manganese, iron, and aluminum) which settle to the bottom of the waste tanks to form a sludge layer. The HHW and LHW are normally segregated. The combined sludge is managed as HHW sludge. In addition to the fresh waste receipt aging, the accumulated HHW and LHW sludge are aged to allow radioactive decay. The aged sludge are transferred to the sludge processing tanks for washing and, if necessary, aluminum dissolution. The HHW and LHW sludge are also combined with each other to provide a consistent effluent waste stream. The washed sludge slurry is transferred to the DWPF Vitrification Facility for vitrification into a solid glass matrix for disposal.

\section{Waste Transfer}

A network of transfer lines is used to transfer wastes between the waste tanks, process units, and the various SRS areas (i.e., F-Area, H-Area, and S-Area). These transfer lines have diversion boxes containing removable pipe segments (called jumpers) to complete the desired transfer route. Various sized and shaped jumpers can be fabricated and installed to allow the transfer route to be changed. The use of diversion boxes and jumpers allow flexibility in the movement of wastes.

The waste flows through the evaporator systems and ITP process building are designed to be conducted on a continuous basis. All other wastes are normally transferred in batches. Transfer of waste from any waste tank to any other waste tank, process unit, or treatment facility is possible with the proper arrangement of pumps, transfer lines, and valves. Administrative procedures are established and followed to ensure that the transfer of wastes is conducted safely and properly.

\section{Waste Removal Program}

The primary objective of the HLW System is shifting from waste storage to removal of radioactive waste from the older style tanks to prepare the waste, including liquid, salt, and sludge, for feed to DWPF. The waste removal program includes removal of salt and sludge by hydraulic slurrying, cleaning the tank interior by spray washing of the floor and walls, and steam/water cleaning of the tank annulus if necessary. The waste processing program includes decontamination of the salt and liquid for incorporation into saltstone and aluminum dissolution and washing of the sludge for feed to DWPF.

The schedules for waste removal and waste processing are closely linked to each other and with the DWPF schedule. The scheduling objective is to remove the waste from the Types I, II, and IV tanks as rapidly as possible without exceeding the capacity of the tank farm processes or DWPF.

Processes and equipment for waste removal and waste processing have been developed and demonstrated in several successful full-scale radioactive demonstrations. Sludge removal by hydraulic slurrying and chemical cleaning with oxalic acid has been demonstrated in Tank 16. Salt removal and sludge removal using mechanical agitation has also been demonstrated on Tanks 15, 17-22, and 24. Facilities have been designed using data and experience gained from these demonstrations. To date, 2.3 million gallons of salt and 1.1 million gallons of sludge have been removed from Types I, II, and IV tanks. 
The Waste Removal Program is a series of projects that install waste removal equipment on the existing waste tanks. The objective of the Waste Removal Program is to remove the waste contained in the tank primary vessel so that the tank can be reused or retired. In general, the Type III tanks will be reused while the Type I, II and IV tanks will be retired when all waste has been removed. The tanks to be retired will also undergo a water washing operation in the primary vessel and an annulus cleaning operation in the annulus if the annulus is contaminated.

Waste removal equipment consists of slurry pump support structures above the tank top, slurry pumps (typically three for salt tanks and four for sludge tanks), bearing water and electrical service to the slurry pumps, motor and instrument controls, tank sampling equipment, tank interior water washing piping and spray nozzles, pressurized wash water supply skids, and heating and ventilation ( $\mathrm{H} \& \mathrm{~V})$ skids to augment the existing tank $\mathrm{H} \& \mathrm{~V}$ during spray washing.

On salt tanks, the slurry pump discharges are positioned just above the saltcake level. Water is added to the tank, the slurry pumps are started and salt is dissolved. The dissolution ratio is typically 2 parts water to 1 part saltcake although this can vary up to 4 parts water per 1 part saltcake. The slurry pumps serve to displace the boundary layer of saturated water in contact with the saltcake and expose the underlying salt to unsaturated water. When the water is fully saturated, the dissolved salt solution is transferred to ITP, the slurry pumps are lowered and the process is repeated.

On sludge tanks, the four slurry pumps are typically positioned in the top layer of sludge, water is added, and the pumps are started. When the layer of sludge is well mixed (i.e. the sludge is suspended) as indicated by sampling, the transfer pump is started and the suspended sludge is transferred to Extended Sludge Processing (ESP). Note that the slurry pumps continue to operate during the transfer so that the suspended sludge does not resettle. The pumps are then lowered, more water is added, and the process is repeated. Sludge tanks require more pumps than salt tanks because the sludge must be agitated vigorously to suspend the sludge particles as opposed to dissolving saltcake.

For tanks that contain mixed salt and sludge, the salt will be removed followed by the sludge. The process is similar to salt removal described above except that the sludge is allowed to resettle before the saturated salt solution is transferred out of the tank.

When the salt or sludge contents have been removed from the old-style tanks, the tank interior is washed with heated water. The water is sprayed throughout the tank using rotary spray jets installed through the tank risers. The water is supplied to the jets by a skid mounted tank and pump system. For those tanks with contaminated annuli, recirculating jets are installed in the annulus through annulus risers and heated water is circulated in the annulus and then transferred to the waste tank primary. At the completion of water washing, there may be some residual waste that cannot be removed with water. Oxalic acid cleaning has been demonstrated in Tank 16 as a viable process to remove the residual waste. However, oxalic acid cleaning is more expensive and, therefore, it will only be considered on a case by case basis depending on the performance evaluation for each tank.

Two new demonstrations will be conducted in FY96-97 to determine if salt removal can be accomplished using less expensive equipment. High pressure water jets will be used in Tank 25 and a process called density gradient will be demonstrated in Tank 41. 


\section{APPENDIX B}

\section{Closure Configuration}

An example of an anticipated closure configuration is described. Note, equipment inside and near the tank might remain in place and several tanks may be capped together.

\section{Tank Closure}

The various layers of material that would exist in a typical tank closure, starting with the bottom layer of the tank and working upward toward the top, would include the residual waste, reducing grout, Controlled Low-Strength Material (CLSM), and strong grout as described below and shown in Figure B-1:

- The residual waste at the bottom of the tank is the waste that could not be removed by waste removal.

- Reducing grout is a grout mixture composed of primarily cement, flyash, and blast furnace slag. The chemical properties of liquid that leaches through this grout will reduce the mobility of certain radionuclides. The formulation of the backfill material for each waste tank may be adjusted based on specific circumstances for each tank. The material is pumped into the waste tank through an available opening.

- CLSM is Controlled Low-Strength Material, a self-leveling concrete composed of sand and cement formers. Similar to the grout, it is pumped into the tank. The compressive strength of the material is limited by using a limited amount of cement in the mixture. The advantages of using CLSM rather than ordinary concrete or grout for most of the fill are:

- The compressive strength of the material can be controlled so that it will provide adequate strength for the overbearing strata and yet could be potentially excavated with conventional excavation equipment. Although excavation of the tank is not planned, filling the tank with low-strength material would enhance the opportunity for future removal of tank contaminants or, perhaps, the tank itself, if future generations were to decide that excavation is desirable.

- CLSM has a low heat of hydration, which allows large pours. The heat of hydration in ordinary grout limits the rate at which the material can be placed, because the high temperatures generated by thick pours prevent proper curing of the grout. Thus, large pours of grout are usually made in layers, allowing the grout from each layer to cool before the next layer is poured.

- CLSM is relatively inexpensive.

- Strong grout is a runny grout with compressive strengths in the normal concrete range. This formulation is advantageous near the top of the tank because:

- The runny consistency of the grout is advantageous for filling voids near the top of the tank created around risers and tank equipment. The grout would be injected in such a manner as to ensure that voids were filled to the extent practicable. This may involve several injection points, each with a vent.

- A relatively strong grout will discourage an intruder from accidentally accessing the residual waste if institutional control of the area were lost. 


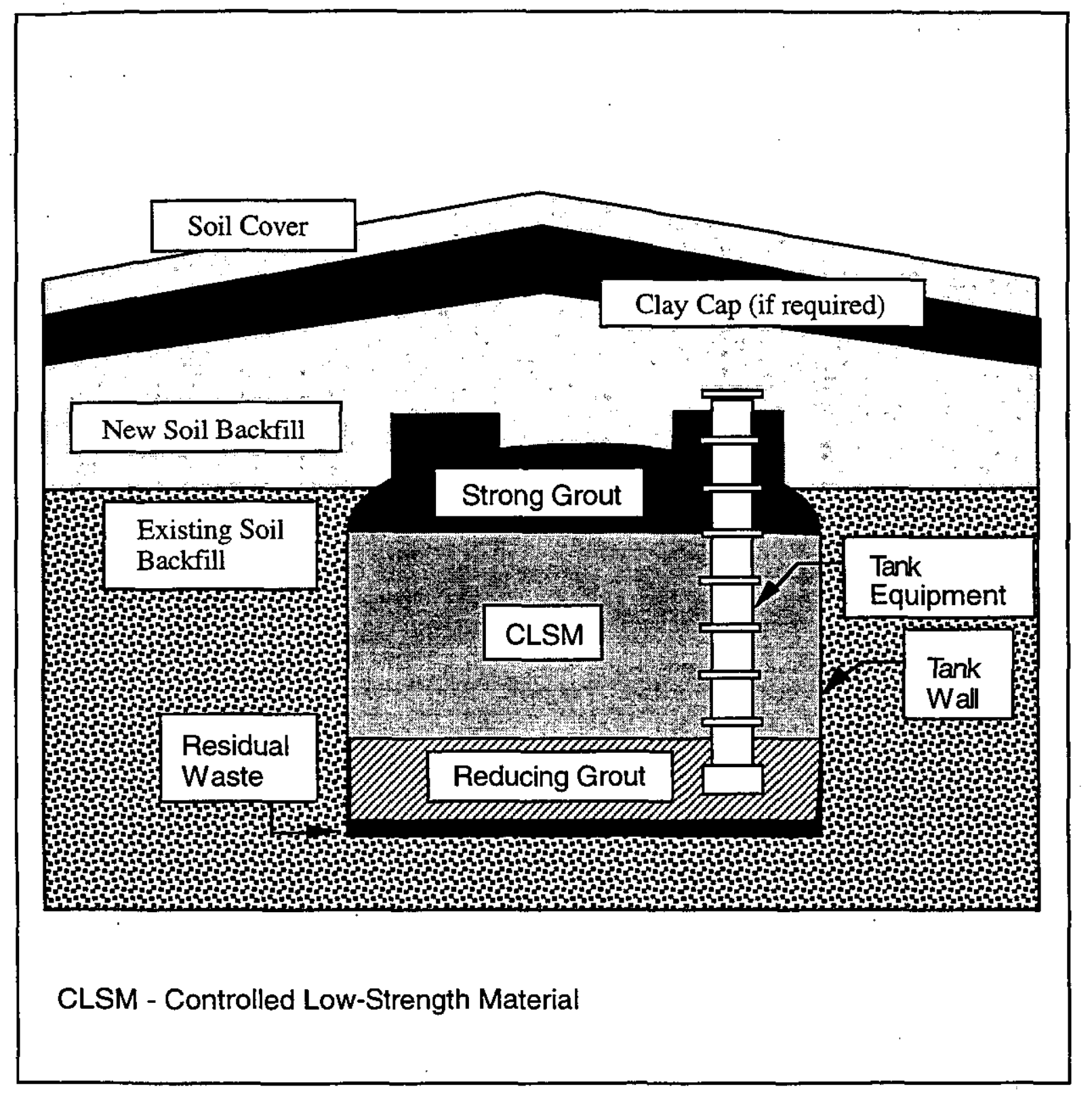

Figure B-1. Typical tank closure configuration

- If required, a low-maintenance engineered cap, such as a clay cap, would be added to reduce rainwater infiltration. First, the area around the tank would be backfilled with soil to cover all risers, equipment, and other protuberances. The cap would then be placed so that rain falling on the area will drain away from the closed tank. Because the tanks are grouped into close groupings, a cap would probably be placed over an entire group of tanks in one area rather than over each tank individually. 


\section{Equipment Closure}

In addition to the residual waste at the bottom of the tank, which is the major focus of closure activities, there will be residual contamination on equipment inside and near the tank, for example, slurry pumps used for waste removal, cooling coils inside the tank, transfer piping into and out of the tank, and the secondary containment system and leak detection system for the tank. In addition, the tank farms include other equipment for processing the waste, i.e., evaporators, pump tanks, and interarea transfer lines from $\mathrm{F}$ - to H-Area and from H-Area to DWPF and Saltstone. The amount of contamination on this equipment is small compared to the amount of contamination in the tanks.

Before closure of a tank or group of tanks, any associated equipment that is planned for reuse (or planned for removal for some other reason) would be removed. Much of this equipment is not contaminated as it does not come in contact with the waste. The pieces of equipment that are contaminated and that would remain after the closure would be decontaminated in a manner similar to the waste tanks (generally by flushing with water or oxalic acid).

Then, all remaining equipment would be filled with pumpable backfill material, similar to that used for tank closure (grout or CLSM) to the extent practical. Existing openings such as hand holes and pipe breaks would be used as much as possible to fill the equipment. Some equipment has small voids that do not present a concern for settling after closure, they may be left unfilled. 


\section{APPENDIX C}

\section{Comparative Analyses of Pre-closure HLW Tank Operations and Post- closure Conditions}

The $51 \mathrm{HLW}$ tanks and ancillary equipment are part of SRS's Liquid Radioactive Waste Handling Facilities (LRWHF). Safety analysis supporting the current operation of the LRWHF has evaluated over 250 accidents; seven of the accidents were rated highest risk, 55 accidents were rated moderate risk and 216 accidents were rated lowest risk. Of the 62 accidents considered highest risk or moderate risk, some were evaluated to be incredible due to an extremely low frequency of occurrence and others were evaluated not to adversely impact the safe operation of the facilities. Thirteen were analyzed as Design Basis Accidents (DBA). The 13 design basis accidents for the pre-closure operation of the LRWHF include the following:

- Seismic Event

- Tornado

- Vehicle Crash

- Transfer Errors

- Benzene Generation from Oxalic Acid and STPB

- Evaporator Breach

- Chemical Spills-Nitric Acid

- Deflagration in Filtrate Hold Tank

- Deflagration in Filter Cell

- Detonation in Evaporator

- Deflagration Transfer Facility

- Liquid Leaks/Spills

- Benzene Uptake - Filter Stripper Building

The following sections describe each accident scenario and assess the scenario impacts in the post closure environment.

\section{Seismic Event}

The Department of Energy requires an evaluation of a Design Basis Accidents (DBA) seismic event. The tank farms and associated facilities are assumed to be operating at the time of the seismic event in a state that will generate the worst case scenario. None of the waste tanks are damaged such that an airborne release occurs. An airborne release results from failure of above ground or near surface transfer lines, assuming a transfer is in progress at the time of the event, and from failure of the evaporators.

Closure of the HLW tanks involves removal or stabilization of the ancillary equipment after the completion of bulk waste removal. With these tasks completed, the source for any possible airborne releases (i.e., surface transfer lines and the evaporators) during a seismic event will have been removed from service. Additionally, the remaining waste heel will be sealed in grout and the remainder of the tank filled with CLSM. This will eliminate any possible airborne release originating from a waste tank during a seismic event after closure.

\section{Tornado}

In the current operational accident analysis the Tank Farms are assumed to be operating (i.e., full of $\mathrm{HLW}$ ) at the time of a tornado/high wind event in a state that will generate the worst case scenario aftermath. All waste tanks are below ground. Type I, Type II, and 
Type III or IIIA waste tanks are protected by at least 22 inches of concrete roof from tornado driven missiles. Type IV waste tanks have at least seven inches of reinforced concrete dome with blacktop above the dome as protection against tornado driven missiles. During a tornado event small lightweight inspection plugs on the tank top could be dislodged. Although some of the tank vapor would escape, no liquid waste would be lost. Additionally, transfer/slurry pumps extending high enough above the risers, as in salt or sludge removal, could be dislodged. This would also result in a loss of vapor, but no liquid waste would escape a tank.

After tank closure, all tank penetrations would be sealed and ancillary equipment (piping, pumps, etc.) would have been removed. There would be no penetrations in the tank. Additionally, after the closure, the tank would be filled with CLSM and there would be no vapor space in the tanks. The remaining waste heel in the tanks would be sealed in grout and covered with many feet of CLSM in addition to the tank walls and tank top. Consequently, there is no mechanism for a tornado induced release.

\section{Vehicle Crash}

Vehicles could contact certain above-grade processing equipment, causing HLW leaks and/or spills to occur. Electric carts, automobiles, light trucks, heavy trucks, and cranes are examples of vehicles that may be in the vicinity of the process equipment from time to time. A crane falling on equipment or dropping significant loads on equipment is another potential initiator that could release radioactivity to the environment. All of these potential initiators are included in the analysis of a vehicle crash.

No main traffic arteries or through roadways exist in the immediate proximity of either tank farm. Therefore, no high-speed vehicular traffic occurs in either tank farm area. In addition, waste tanks are massive structures whose exterior walls are either underground or surrounded by an earthen berm, making them impenetrable by a vehicle of any type. The exposed surfaces of waste tank concrete roofs are generally located at an elevation that is a foot or more higher then the elevation of adjacent vehicle roadways. This elevation difference would thwart encroachment by most vehicles, especially at the low speeds required to negotiate the roadways in the tank farms. Studies have shown that tank tops would also withstand the impact loading of a three-ton truck. No release of HLW from a waste tank would occur due to a vehicle impact.

After tank closure all but a small waste heel (sealed in grout) will be removed from the tank, all ancillary equipment will be removed or stabilized, all tank penetrations will be sealed and the tank will be filled with grout and CLSM. Essentially filling a tank with backfill material will greatly increase the tank integrity and provide an impervious barrier with respect to vehicle impact. During tank closure the grout and CLSM will be pumped from a distance into the tanks, thus eliminating the need for increased vehicle traffic in the immediate vicinity of the tanks during the closure process.

\section{Transfer Errors}

During current operations of the tank farms, waste handling requires multiple transfers of liquid solutions or slurries. An incorrect transfer of waste (transfer error) within the LRWHF is an operational event that may result in a release of HLW. Potential transfer errors encompass a broad range of operator activities that can lead to various types of material release.

Tank closure will occur after bulk waste removal. Therefore, there will be no waste transfers after tank closure. 


\section{Benzene Generation from Oxalic Acid and STPB}

This accident is an operational event involving a benzene release that is generated by the mixing of sodium tetraphenylborate (STPB) and oxalic acid. The STPB is delivered directly to the pumping station in the cold feed area by tanker trucks that have an assumed maximum volume of 5000 gallons. Although STPB is directly delivered to the pumping station in the Cold Feed Area, the possibility still exists that the STPB and oxalic acid can inadvertently be mixed in the Cold Feed Area.

This accident does not involve the waste tanks and, therefore, is not germane to discussion of the tank closure project.

\section{Evaporator Breach}

An evaporator breach does not involve the HLW tanks. Furthermore, after bulk waste removal, the evaporators will be out of service. Therefore, a discussion of an evaporator breach is not germane to the tank closure project.

\section{Chemical Spills-Nitric Acid}

Nitric acid is stored in a 10,000 gallon tank in the Effluent Treatment Facility (ETF). Consequently, a nitric acid spill would not originate from the HLW tanks. Therefore, a discussion of a nitric acid spill is not germane to the tank closure project.

\section{Deflagration in Filtrate Hold Tank}

The function of the Filtrate Hold Tank (FHT) is to hold the filtrate (or spent wash water) until it is analyzed for transfer acceptability. The filtrate is a decontaminated salt solution. After bulk waste removal, the FHTs would be out of service and, therefore, are not germane to the tank closure project.

\section{Deflagration in Filter Cell}

The filter and associated piping are located inside a shielded area of the Filter Building called the filter cell. After bulk waste removal, the Filter Building will be out of service. Additionally, a deflagration in a filter cell does not involve the HLW tanks. Therefore, a discussion of a deflagration in a filter cell is not germane to the tank closure project.

\section{Detonation in Evaporator}

By the time the HLW Tanks are closed, the evaporator will be out of service. Therefore, accidents associated with the evaporator are not germane to the tank closure project.

\section{Deflagration Transfer Facility}

The transfer systems move waste from one tank or facility to another tank or facility. Closure of the HLW tanks will occur after the bulk waste removal (i.e., after the waste tanks have been emptied). Therefore, the transfer systems will not be in service and accidents involving the transfer systems would not be possible. 


\section{Liquid Leaks/Spills}

This is an operation event that involves the leakage or spillage of HLW. The leaks considered in this scenario are those caused by piping or equipment failure. Closure of the HLW tanks will occur after the bulk waste removal (i.e., after the waste tanks have been emptied). Therefore, the transfer systems will not be in service and accidents involving the transfer systems would not be probable.

\section{Benzene Uptake - Filter Stripper Building}

Benzene is released through the stack during normal stripper column operation and during stripper column cleaning with oxalic acid. If benzene is accidently ignited in the stack, a deflagration may occur, resulting in an overpressure, with the potential to rupture the stack. The stack outlet is 90 feet above ground level, but a rupture may cause the stack to release unburned benzene at a lower height. This is an operational event and could potentially expose nearby personnel to the hazardous chemicals being released from the stack.

Closure of the HLW Tanks will occur after the bulk waste removal (i.e., after the waste tanks have been emptied). Therefore, the Filter Stripper Building will not be in service and accidents involving the Filter Stripper Building would not be germane to the tank closure project. 


\section{APPENDIX D \\ RESPONSE TO PUBLIC COMMENTS}

Table of Contents

Number

Title

Page

\begin{tabular}{|c|c|}
\hline --- & Introduction \\
\hline $\mathrm{L}-01$ & Sam Booher \\
\hline $\mathrm{L}-02$ & Sam Booher \\
\hline-- & Department of Energy Response to L-01 and L-02 \\
\hline L-03 & Tony Maxted \\
\hline$\ldots$ & Department of Energy Response to L-03 \\
\hline L-04 & Glenn Beaumier \\
\hline-- & Department of Energy Response to L-04 \\
\hline L-05 & Eugene L. Graf \\
\hline & Department of Energy Response to L-05 \\
\hline L-06 & State of South Carolina \\
\hline
\end{tabular}

D-1

D-2

D-3

D-4

D-5

D-6

D-7

D-13

D-22

D-25

State of South Carolina

D-32 


\section{INTRODUCTION}

On March 23, 1996, the U. S. Department of Energy Savannah River Operations Office (DOE-SR) decided to initiate the preparation of an Environmental Assessment (EA) for the closure of the high-level waste tanks in F- and H-Areas on the Savannah River Site (SRS). This document preparation effort was implemented in compliance with the National Environmental Policy Act (NEPA) of 1969, as amended, the requirements of the Council on Environmental Quality Regulations for Implementing NEPA (40 CFR Parts 15001508), and the DOE Regulations for implementing NEPA (10 CFR 1021). The assessment of environmental consequences of Federal actions that may affect the quality of the human environment are required under NEPA. Based on the potential for impacts described in the resultant document, DOE will either publish a Finding of No Significant Impact (FONSI) or prepare an environmental impact statement (EIS).

An initial internal scoping meeting was held on March 28, 1996 for this EA pursuant to the guidelines specified in the Savannah River Site NEPA Program Quality Assurance Plan Preparation and Review of Environmental Assessments (WSRC-RP-96-010). The proposed action, alternatives, specific assessment studies needed, project time frame, and public participation were discussed at that meeting. Preparation of the preliminary draft EA was begun in late Match of 1996. The preliminary draft EA was completed in late May of 1996. As required in 10 CFR 1021, the predecisional draft EA was transmitted to the states of South Carolina and Georgia on June 4, 1996 for review and comment. The end date for comments from the states was scheduled for July 20, 1996. A total number of six responses were received, ranging in length from one to six pages. Agency responses numbered one; individuals provided five comment responses. As indicated in in the comment responses, the EA has been changed, where appropriate, to address commentors concerns.

The comments and responses follow: 


\section{Andrew R. Grainger}

SPNEPA Compliance Otlicer

Department of Energy

Savannah River Operations Ollice

Building 773-42ANPOom 212

Aiken; Soulh Carolina 29808

to you have an idea, suggestion, or official scoping comment to qake? If so, please write it below and mail-in this card.

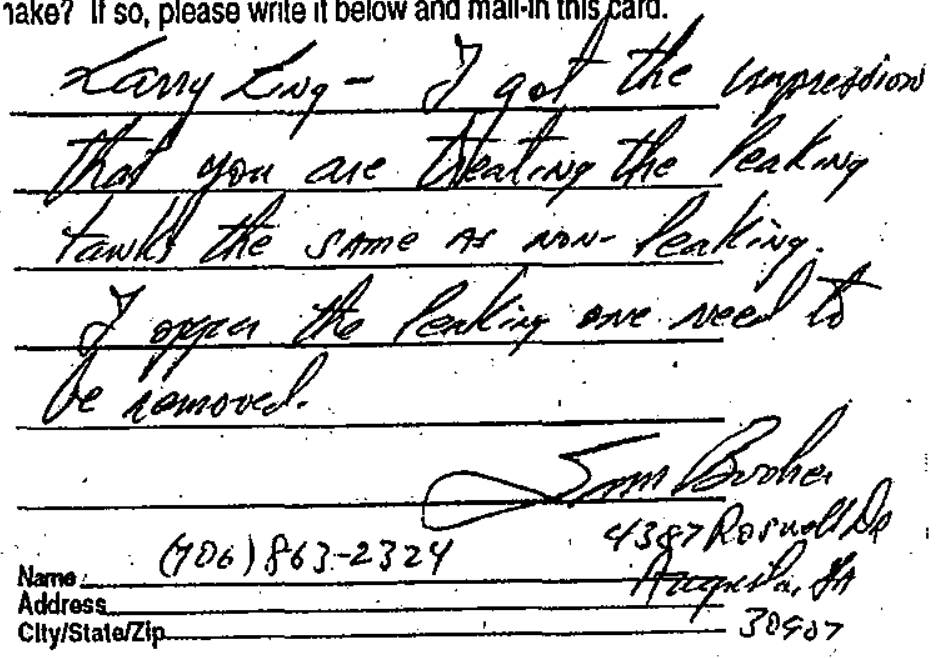


L-02

Mr Andrew Grainger

Elox A. SRS

Deat Mr Grainger.

While I am very pleases that you ineld a Public Meeting on 11 June concerning Closure of the High level Waste Tank and not. in

What I did hear is that you are going to begin closure. of the old Tanks. This $r$ was pleased. However, what I did not hear is that. you are wor treating the cracked and

T the in different thot the intact tanks.

got the impression that you warit to set rid of this to do this you are ready to just fill them with concrete and forget thern.

Again, I have no problem with this solution as long as you are taiking about the intact tanks.

However, those that have leakod High tevel wast $\theta$ need

to be removed and the spilled High level waste at leost

inspected and dealt with oroperly. Not just, covered with concreted and ignored.

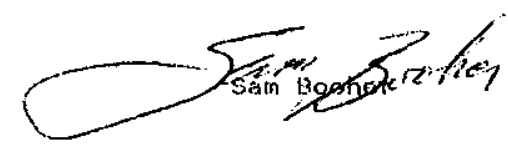

See DOE response letter on page D-4 
DOE Response to letters

L-01 and L-02 pages

D-2 and D-3
Department of Energy

Savannah River Operations Office$$
\text { P.O. Box A }
$$

Aiken, South Carolina 29802

\section{d4. $24 \quad 1395$}

Mr. Sam Booher

4387 Roswell Road

Augusta, Georgia 30907

Dear Mr. Booher:

SUBJECT: Industrial Wastewater Closure Plan for F- and H-Area High-Level Waste Tank System and Draft Environmental Assessment (EA) for the Closure of the HighLevel Waste Tanks in F- and H-Areas at the Savannah River Site (SRS)

This is in response to your letter of June 18, 1996, recommending not using the same proposed closure treatments for both leaking and non-leaking high-level waste tanks at SRS. Your letter, and the Department of Energy's (DOE) response, will be included in the Final EA (DOE/EA 1164).

The soil in and around cach high-level waste tank will be characterized after tank closure Remediation, if necessary, will be in accordance with the Comprehensive Environmental Response, Compensation, and Liability Act requirements. Therefore, soil contamination from any tanks that have leaked will be remediated prior to closure of the tank farm area. Tanks that have leaked and those that have not leaked detectable amounts of waste will be closed following the requirements and performance objectives stated in the closure plan and the tank-specific closurc module. 'Subsequent to waste removal operations and stabilization of residual waste, the potential and risk of liquid waste migrating out of the tanks is eliminated. DOE believes it is important to recognize that implementation of the closure plan by removing waste and stabilizing the residual in the tanks, greatly reduces the quantities of high-level waste that may be released to the environment in the future. All the high-level waste tanks are constructed from carbon steel and will fikely corrode and disintegrate in the future. By implementing the closure plan, DOE can assure that the consequences are not significant.

If you have further questions or require additional information regarding this proposed action, I can be reached at $803 / 725-1523$.

Sincerely,

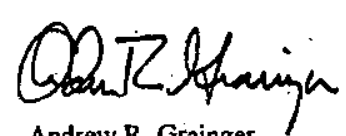

Andrew R. Grainger

Engineering and Analysis Division

EAD:SAD:cl

SR NRPA Compliance Officer 


\author{
Andrew P. Grainger \\ SR/NEPA Compliance Otficer \\ Department of Energy \\ Savannah Aiver Operations Office \\ Building 773-42ARoom 212 \\ Aiken, South Carolina 29808.
}

Do you have an idea, suggestion, or official scoping comment to make? If so, please write it below and mail-in this card.

I am concerined that DOE is seeking to close.

the tanks remoning then from possible future ase.

before the long-term future of canyon rperations 2

SRS. in determined. Causidering the cursent tack of capacity \& presure on the evaporator systems. I cannid

see a cogent arguement for rearterm final closute; (emptying-yes, closure - no) of: reusable tanks.

Naine TonY Maxted

Address $10.6 \mathrm{~g}$ SLWER BUILR RA

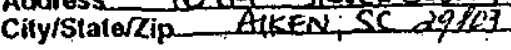


DOE Response to letter L- 03 on page $D-5$
Department of Energy

\section{Savannäh Rlver Operations Office}

P.D. BoxA

Aiken, South Carolina 29802

$\because$

ain 241986.

Mr. Tony Maxted

1069 Silver Bluff Road

Aiken, South Carolina 29803

Dear Mr. Maxted:

SUBJECT: Industrial Wastewater Closure Plan for F- and H-Area High-Level Waste Tank System and Draft Environmental Assessment (EA) for the Closure of the HighLevel Waste Tanks in F- and H-Areas at the Savannah River Site (SRS)

This is in response to your concern received as a result of the June 11, 1996, public meeting regarding the closure of non-leaking high-level waste tanks prior to determining the long-term future of the Canyon operations at SRS. Your letter, and the Department of Encrgy's (DOE) response will be included in the Final EA (DOE/EA 1164).

In accordance with the Federal Facilities Agreement, the Types I, II, and IV tanks that will be closed cannot be used to receive any fresh waste and consequently closure of these tanks will not impact any potential future missions. The Type III tanks will be scheduled for closure based on identified current mission needs. As new missions are identified, DOE will reevaluate closure of these tanks. All the tanks are made of carbon steel and in the future will likely corrode and disintegrate. Subsequent to waste removal, the residual waste will be immobilized to minimize the risk from potential leaks. Emptying the tanks; which are nearing the end of their useful life, and not stabilizing the residual waste is not a prudent option.

If you have further questions or require additional information regarding this proposed action, I can be reached at $803 / 725-1523$.

\section{Sincerely,

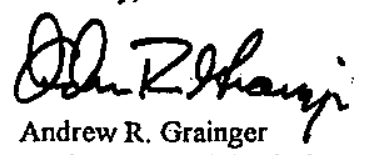

EAD:SAD:cll

Engineering and Analysis Division

VA-0003

SR NEPA Compliance Officer 
To: anthonvo2. rouns

(anthonvo2.toins

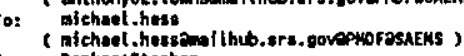

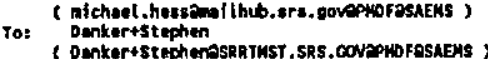

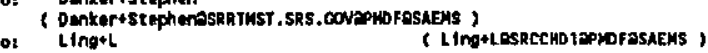

Fromi Graingertbrew
Fron:

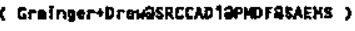

Rec Iank Clozure Plen ond EA Coprents

INIER-OFFICE MERORANOUM
SAYAMSh River site

Sovarnath River site

07-Jul-1996 07:39pn Est

To: Androw.grainger

Cc: kelly.woy

(kelly.waymal litub. ors.povaphoroskens)

from: grb

( grbagroepz. netapupasaens )

Ienz closure plan end Es corments

Glem R. Bnatunier

312 setile path rood

July 6, 1996

Andrex R. Grainger
SR/MEPA Conplitince officer

SR/MEPA Compli ince of

Ssyernath River Operations office

gullding $773 \cdot 42 M / R$ Roon 212

thenk you for the opportunity to conement on the closure Plan and

Enviformenter Aacesenent of the 51 Miph Levat Haste tenks at the Savernah Rivar site. specific compents are attached, but i cun briefly summarize my concerne for you.

The general path forwerd apposers to hove boen put together rather hastily. The documents out far review seen to try and justify a decislon mode before ary ol ternatives unalysis for closure mere perforaed. The al ternatives

complete. The proposed activlty (grouting in ploce) is rother (rreversible.
i cempot understend the ruah to move forward without a serious evaluotion of 
Comment No.

L-04 etternetives and proposed mitigating actions if the solected alternative

Continued folle meet Its objectives.

SRs does not have on outstanding record of havine thinge work carrecely on

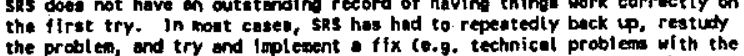

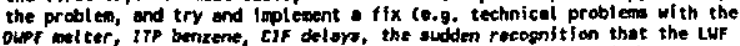
was needed, $z$-Aree vevit crecking, ... I could go on). Kost of these probleme can be sttrifuted to A failure to study the problem before

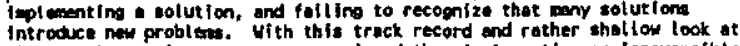

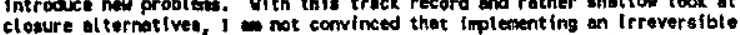
clotiure on the firet try is a cart thing to do. One thing that ench al ternative meeds is o probebility that it will fall and the cost to remedy the fallure. In this way, onore expensive, yet reversible option of ght be Intering closure in the bapt

path forward unth sRs hus o better

Laztly, 1 would like to request the name of the individual who is

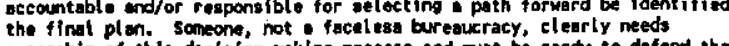
the firat plan. Someone, not a facel asa bureaucracy, clearly needs technieal merit of thelr actions. Right now, technical merit and

Sincerely.

Glem R. Bencuter

tC: Kolly yay (kellly. woyesre.gov)

Atrechment

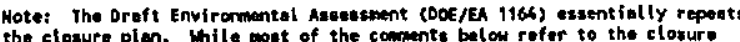

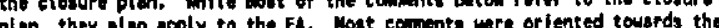

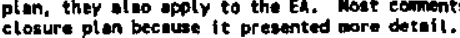

1) In gemeral, the altornetives oppear to be ovoturted at follows. grounduater contenlnat

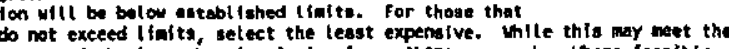
tow coat increnentol toprovements should be exployed to mininize future prounchater conteminotion.

For exsmple, before grout emplecenent, the spray wash nozzlos could be used to dollvere gelint or other water imporvious coating (e.g. epony) to fix os

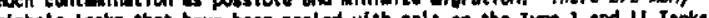
and peselbly the Tye IY's. A coesting ayaten night re-plug these holes for many years end nininalze future releoses untit some isorobes decty. In addition, cothodic protection could be provided to the steel tank structur (Impressed eurront, secrificial onoces, modizoc the tank wall, etc) to ide trenendous benefits. These are onty

some examples of inexpensive incrementsi actions consistent with MLARA.

2) The alternetiven analysis (closure plan page 4-1) states that the fill
See DOE response letter on pages D-13 to D-21 
L-04

Continued meteriel will be high in pH and compastble with the carbon eterel tanks.

ragularly onityed to the SRs tanks to mintain fivorable choosintry. Once the hydroxide fon is consumed in a grouted tonk, there will be no wey replonish it, or even measure that it is ons. Locil ized ehenical corrosion

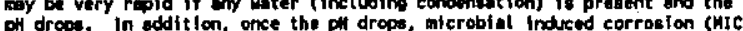
may be problem. SRs hase sl heady encountered thic probted inere well water bo given to the sRs Emil romentel Restorat ion Progrem

cource control or remediation of contaminant relessez wits be porforpod. If

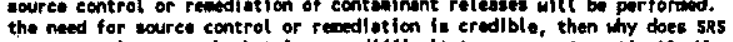
propose I closure poth that is very difficult to reverse (grouting)? thy

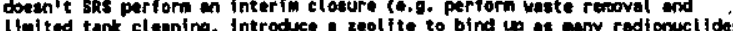
as ponefble, dry the waste as moch as feasible, seal all tank openings for wator intrusion, then monitor n? How will the SRS Emviromentol Restorazion

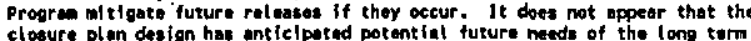
custodien.

It ts not clear why there is a rush to irreverstbly close these tenke in the 4) The closure plan (poge 6-11" states that the "ffoll lowlng techniques or

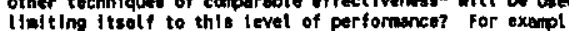

will be waed, why not add fritt and high preasure to the equartion?

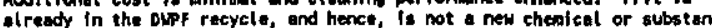
to doal with.

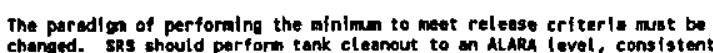
Wh th the reguletory framework. As atseted on closure plon page 3-2, SAS oust remove og much radioset tvity as positble waine procestes that are technically and econemically prectcable wh order for the residue to be miesing fron the closure plon. SRe continuality eppearl to be caing the sbasoluth minitem to got by. Thls does not portroy sks as being a good

5) Closure plen page 4-3 mentions that the sucondary conteiment annulus of

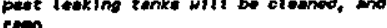

ved. Please define practicol of the criteris for suctesuful elsaning. Uithout ach criteris speciffiod in worrance, who will deterwine how clean is cleans Hon will the voluse and curie cant of the waste renaining in the ampuluo bo estizoted it would be a poor osiumption that the waste in the

6) Page 4.3 of the closure plem ataten that ech tank wIll be evaluetod to

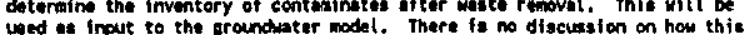
avaluatlon will be performed, no atempling methods are disecussed. The entire closure plan grounowater model ing concept hingee on thle date input coerbage

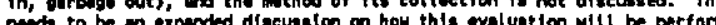
and why the resulte are considered reprecentative. This ovaluation needs to include moturiole trapes din dieposod equiphent, rasidue on the tank valle,
See DOE response letter on pages D-13 to D-21 


\section{L-04 \\ Continued}

11 thin smpling indicotes that the materlal crosidue of contaninated tho meteriol be removed and sent to tho ulpp or other TRU repository

7) Closure plen page 4-6 discusses post ctosure mont toring and inspection

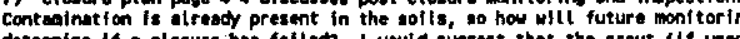
deternine if elasure

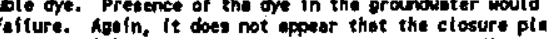
design has intisipoted potential future neecta of the long tera custodian.

8) Page 4.4 discusies tenk stabilization. Why did the elternative study Iinit Itsolf to grout, sand, and clan thy weren't other water impermeeble

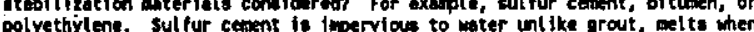
heated (e.g. heat it 4 to 20 degrees $c$ and pamp ft out it ever needed),
has high coppressive strength, is o good binder for waste, and is a proven

9) Page 4-6 of the closure plan discusses ancillary equipnent. If water incervsion fs the prinary method for migration of contmination, ghould't

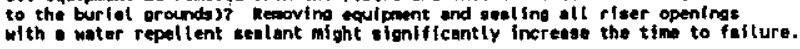

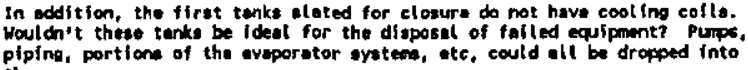
tunk and diaposed of sfixod in plece by grout or inplement ing other clogure al ternativas). Larger equipment could be broken to at the $299 \mathrm{~W}$, the

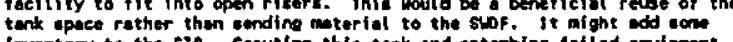

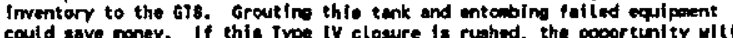
could save noney. if thic inpe if closure is rushed, the opsort ton ty uill

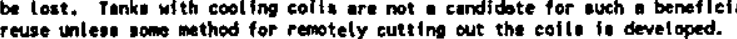

10) Page 6-5 of the closure plen difcusses ussupptions in the GTS. that if

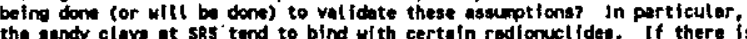
ion exchenge in the soft and creste mot spots"

11) Pape A-

A.1 of the closure plan presenta omerix of st ternatives. matrix should not inclube al ternotivoe o and E because they were not seriously ovatuated and carnot be compared to the other al ternativea. Page argue that the coste ssaimed for alternotive D ara grosaty axaggerard prenoturely remove this alternative fros onluation. The first tank would undochtably be an expereive clasure, but once the wquiphent was purchased be broken into several different options of increasing efficacy and cost

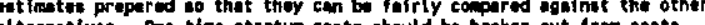

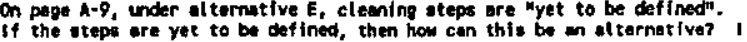

See DOE response letter on pages $D-13$ to $D-21$ 
Comment No.

\section{Comment}

L-04

Continued auggert that wome method be selected and cost outinated so that there is a for comparison with other options.

Many of the mothods (under altornatives D and E) muat be doveloped to resolve waste resovel problene it henford. If the methoda muste be developed and perferted, why doesn't sess develop them so they yilli be ready when

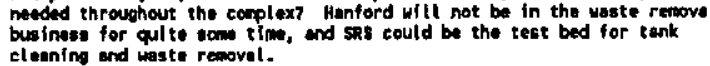

At this time, alternotive $C$ has boen selected. If alternativos $A$ through $E$ of the an increasing order of acted inal alternative sulection, at a minimen, please present. Bare in depth

12) Consistent with AlarA, 1 did not ces my rest discussion on renoving

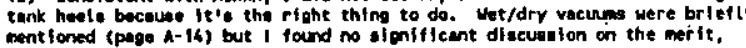
post iblitty, or teent

IIty of removing tank heols beyond the 3000 to 4000

atlion level. Wone of the alternatives discuss complete heel removol. An

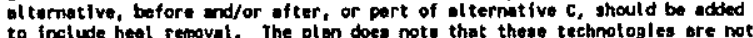
meture at this timo. Why aren't they coveloped and used as pert of the clonure proceas? What is the impect of walting s fen years?
such a rush to close the first tanka? Also, see comment 14 .

13) Why is there no mention of trestimento such as insitu viterification or calcining there leaving a heat would be less of a concern?

16). On page $A-7$ of the closure pion, the no action alternative is discussed. The time frome for the navelyeis is not clear. How long do wo

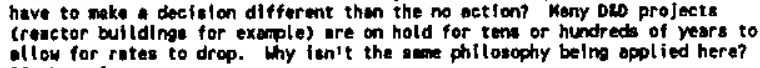
if the primary

worker dose for option $E$ is 93 man ren (page A-7), primorliy

from Cs 137. then wisting 60 years would cut the dose to 25 man remp would

costly due to the time yolue of money. Is there an immediate sofety concern that is driving closure of the first tark in 1996? It is not cleor thy there 18 guch o rush. According to the EA (pape
least 2028 to elose the iype 1, 11, and IV tonke.

15) Page A-11 of the closure plan clalma that sproy nozzles cen rearove cludige troathe odges of the tim. the ranka can be resturried, and the

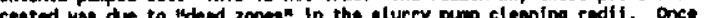

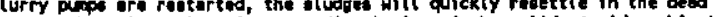
zonos. The only roal options are dissotution of the soll (acid woshing)

16) The Ex, poga 1, $11 \mathrm{me} 23$ claime that the best ovall

technology wili be uand to remove wazte from the tenks, including the hoelo.

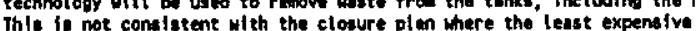
technology that moets grounduater modeling parmeters is selected. Tho discrepency meede to be restolved one way or the other.

17) Given the opt lons considared fand the proposed al ternative on grout Ing in places, this appoere to be s major fedoral action. The proposed al ternative will asometicity restrict the vas of the lend in the tank farm aroes (ond downoredient lend) for several shousand years (or "forever" vias
Response

See DOE response letter on pages D-13 to D-21 
L-04 million times 24 tanks, or $\$ 1.2$ billion by 2028 . Either way, this looks

like a major federal action that would have significant local impacts. What

Cont-d is the bases for an EA rather than on EIS?

18) The closure plan and EA mention that no robotic arms are available that can navigate through the forest of cooling coils. Why not have a roboti

c

arm just cut away the cooling coils and let them drop to the bottom of the

tank? Simply cutting away the coils appears to open up or make other

al ternatives appear more attractive.
See DOE response letter on pages D-13 to D-21 
DOE response to letter $\mathrm{L}-04$ on pages $\mathrm{D}-7$ to $\mathrm{D}-12$

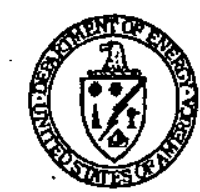

.
Department of Energy

\section{Savannah Fiver Operations Office}

P.O. Box A

Aiken, South Carollna 29802

.لIL 241996

Mr. Glenn R. Beaumier

312 Bridle Path Road

North Augusta, South Carolina 29841

Dear Mr. Beaumier:

SUBJECT: Industrial Wastewater Closure Plan (CP) for F- and H-Area High-Level Waste Tank System and Draft Environmental Assessment (EA) for the Closure of the High-Level Waste Tanks in F- and H-Areas at the Savannah River Site (SRS).

This is in response to your email of July 6,1996, commenting on the stated subject. Your email and the following Department of Energy-Savannah River (DOE-SR) response, will be included in the Final EA (DOE/EA-1164).

Beaumicr comment 1: In general, the alternatives appear to be evaluated as follows. Identify the alternatives where ground water modeling indicates future groundwater contamination will be below established limits. For those that do not exceed limits, select the least expensive. While this may meet the letter of the law, what is missing is an ALARA approach. Where feasible, low cost incremental improvements should be employed to minimize future groundwater contamination.

For example, before grout emplacement, the spray wash nozzles could be used to deliver a paint or other water impervious coating (e.g. epoxy) to fx as much contamination as possible and minimize migration. There are many pinhole leaks that have been sealed with salt on the Type 1 minimize migration. There are many pinhole leaks that have been sealed with salt on the Type 1
and II Tanks, and possibly the Type IV's. A coating system might re-plug these holes for many years and minimize future releases until some isotopes decay. In addition, cathodic protection could be provided to the steel tank structures (impressed current, sacrificial anodes, anodized the tank wall, etc.) to prolong their lives and minimize releases. These additional measures are not all that expensive, but may provide tremendous benefits. These are only some examples of inexpensive incremental actions consistent with ALARA. There are many more.

DOE-SR response 1: As low as reasonably achievable (ALARA) considerations are an utmost priority with the DOE-SR Tank Closure Program. Where feasible low cost incremental improvements will be employed to minimize future groundwater contamination. Each individual tank or group of ground transport segment (GTS) related tanks will and must meet performance objectives approved by SCDHEC. A reducing grout is expected to bind the remaining radionuclides in the residual waste in the tanks. Fixing and repairing pinholes and cracks are only a short term solution. Eventually, the tanks will begin to degrade after their average life expectancy of 50 years. Many are approaching these limits now. This is another governing 
DOE response to letter $\mathrm{L}-04$ on pages D-7 to D-12

\section{Glenn R. Bcaumier}

improving the environment at SRS.

Beaumier comment 2: The altematives analysis (closure plan page 4-1) states that the fill material will be high in $\mathrm{pH}$ and compatible with the carbon steel tanks. This will only be true for a short period of time. Caustic inhibitors are regularly added to the SRS tanks to maintain favorable chemistry. Once the hydroxide ion is consumed in a grouted tank, there will be no way to replenish it, or even measure that it is gone. Localized chernical corrosion may be very rapid if any water (including condensation) is present and the $\mathrm{pH}$ drops. In addition, once the pH drops, microbial induced corrosion (MIC) may be a problem. SRS has already encountered this problem where well water has been in contact with buried carbon steel for extended periods.

DOE-SR response 2: DOE recognizes that High Level Waste (HLW) tanks will corrode in the futurc. Modeling does not take any credit for the tank and tank structures remaining intact. The impacts of chemical and physical decomposition on the carbon steel tanks are analyzed and planned for in the modeling process.

Beaumier comment 3: The closure plan (page 4-1) indicates that the post closure custody will be given to the SRS Environmental Restoration (ER).Program, and if necessary, source control or remediation of contaminant releases will be performed. If the need for source control or remediation is credible, then why does SRS propose a closure path that is very difficult to reverse (grouting)? Why doesn't SRS perform an interim closure (e.g. perform waste removal and limited tank cleaning, introduce a zeolite to bind up as many radionuclides as possible, dry the waste as much as feasible, seal all tank openings for water intrusion, then monitor)? How will the SRS Environmental Restoration Program mitigate future releases if they occur. It does not appear that the closure plan design has anticipated potential future needs of the long term custodian. It is not clear why there is a rush to irreversibly close these tanks in the immediate future.

DOE-SR response 3: Characterization of the soils around the closed tanks will be for existing releases and not for future releases. These areas are the responsibility of the SRS ER Program which will be governed when the tank farm area is closed later under a Comprehensive Environmental Response, Compensation, and Liability Act (CERCLA) closure. Monitoring wells will be installed around closed tanks per the BR Program where needed and required to detect future releases, if any, and will provide adequate tine for compensatory measures to be taken prior to reaching points of compliance.

The anticipated future needs of the tank farms will be limited to industrial use only and no drilling or use on tank tops will be allowed. The entire. SRS site and its individual areas, as far as future uses go, are defined and controlled by the SRS Future Use Plan which is publicly available.

DOE has set a priority to remove waste at SRS by the year 2028 as stated in the Federal Facilities Agreement, a tri-party agrecment with SCDHEC and EPA. HLW is working towards this goal with vitriftcation of waste at the Defense. Waste Processing Facility (DWPF) and tank closure 
DOE response to letter L-04 on pages D-7 to D-12
Glenn R. Beaumier

activities. The Citizens Advisory Board, SCDHEC, and EPA Region IV are interested in and are pushing for DOE to act now on tank closure.

Beaumier comment 4: The closure plan (page 4-1) states that the "following techniques or other techniques of comparable effectiveness" will be used. Why is SRS limiting itself to this level of performance? For example, if water washing will be used, why not add frit and high pressure to the cquation? Additional cost is minimal and cleaning performance enhanced. Frit is already in the DWPF recycle, and hence, is not a new chemical or substance to deal with.

The paradigm of performing the minimm to meet release criteria must be changed. SRS should perform tank cleanout to an ALARA level, consistent with the regulatory framework. As stated on closure plan page 5-2, SRS must remove as much radioactivity as possible using processes that are technically and economically practicable in order for the residue to be declared incidental waste by the U.S. Nuclear Regulatory Commission (NRC). Implementation of this concept is missing from the closure plan. SRS continually appears to be doing the absolute minimum to get by.' This docs not portray SRS as being a good environmental steward.

DOE-SR response 4: The extent of cleaning/waste removal has been agreed upon by the regulators as practicable and feasible. DOE must meet the approved performance objectives in order to close each tank. If a tank cannot meet these performance objectives, then other means such as you mentioned will be studied. However, if a tank still cannot meet the performance objectives, a CERCLA closure will ensure compliance on a tank-by-tank basis.

Beaumier comment 5: Closure plan page 4-3 mentions that the secondary containment annulus of past leaking tanks will be cleaned, and as much waste as practical will be removed. Please define practical of the criteria for successful cleaning. Without such criteria spocified in advance, who will determine how clean is clean? How will the volume and curie count of the waste remaining in the annulus be estimated? It would be a poor assumption that the waste in the annulus after cleaning is homogeneous and surface samples are representative.

DOE-SR response 5: The secondary containment (annulus) will be cleaned, and as much waste as practical will be removed according the performance objectives approved by the regulators. Again, the performance objectives must be met before a tank can be considered closed. All of the tank specific performance requirements will be spelled out in detail in the tank specific closure module. In general, it has been decided by the regulators that bulk waste removal and spray washing is acceptable. However, DOE-SR will meet contamination requirements of less than 4 mrem/year at the seeptine.

Beaumier comment 6: Page 4-3 of the closure plan states that each tank will be evaluated to determine the inventory of contaminates after waste removal. This will be used as input to the groundwater model. There is no discussion on how this evaluation will be performed, no sampling methods are discussed. The entire closure plan groundwater modeling concept hinges on this data input (garbage in, garbage out), and the method of its collection is not discussed. 
DOE response to letter L-04

on pages D-7 to D-12

\section{Glena R. Beaumier}

There needs to be an expanded discussion on how this evaluation will be performed and why the results are considered representative. This evaluation needs to include materials trapped in disposed equipment, residue on the tank walls, cooling coils, HVAC system, etc., not just the residue on the bottom of the tank.

If this sampling indicates that the material (residue or contaminated equipment) is greater than $100 \mathrm{nCi} / \mathrm{gram}$ of Transuranic (TRU) isotopes, shouldn't the material be removed and sent to the WIPP or other TRU repository? Failed equipment from the Canyons is removed and targeted for WIPP, would tank farm failed equipment be treated the same way?

DOE-SR response 6: The closure plan describes the sampling methods and the process in which the inventory of contaminates after waste removal will. affect groundwater hydrology. Groundwater wells and monitoring programs will provide the needed data to support and prove any leakage into the streams and surface water on SRS. The requirements will be discussed and detailed in the tank specific closure module beforc any tank closure activities are started.

DOE-SR expects the samples of the residue or contaminated material will contain less than $100 \mathrm{nCi} / \mathrm{gram}$ of TRU isotopes. However, if the tank residue is higher, another evaluation will be required. Tank farm failed equipment is deinventoried and decontaminated onsite or by fixed price contract. At this time no plans are being made to transfer this equipment to WIPP or a TRU repository elscwhere.

Beaumicr comment 7: Closure plan page 4-4 discusses post closure rnonitoring and inspection. Contamination is already present in the soils, so how will future monitoring determine if a closure has failed? I would suggest that the grout (if used) include a water soluble dye. Presence of the dye in the groundwater would indicate a closure failure. Again, it does not appear that the closurc plan design has anticipated potential future needs of the long term custodian.

DOE-SR response 7: It -is very difficult to study and determine the success and/or failure of the grout material once it is inside the tank. In time, the tank structure will erode causing the contaminants to enter groundwater and soil, which modeling shows it will take thousands of years. As long a funding is provided - DOE-SR will be monitoring this activity via wells and surveillance. Eventually, some constituents will be released to the environment, therefore, surveillance. Eventually, some constituents will be released to the environment, therefore,
DOE-SR will employ monitors to detect and measure the radionuclides. If any releases occur, DOE-SR may be required to remediate under future programs.

The closure plan and the future site use plans describe the potential future needs of the tank farms and the SRS areas.

Beaumier comment 8: Page 4-4 discusses tank stabilization. Why did the alternative study limit itself to grout, sand, and clay? Why weren't other water impermeable stabilization materials considered? For example, sulfur cement, bitumen, or polyethylene. Sulfur cement is impervious 
DOE response to letter $\mathrm{L}-04$ on pages D-7 to D-12

\section{Glenn R. Beaumicr}

to water unlike grout, melts when heated (e.g. heat it up to 120 degrees $C$ and pump it out if ever needed), has high compressive strength, is a good binder for waste, and is a proven technology.

DOE-SR response 8: Grout is a generic term that may include radically different constituents. Experts are looking into other materials such as bitumen which will be based on available costs and experience. At this time, grout has been determined as the best material but other binding materiais will be considered on future tank closings.

Beaumier comment 9: Page 4-6 of the closure plan discusses ancillary equipment. If water intrusion is the primary method for migration of contamination, shouldn't all equipment be removed from the risers and inserted into the tank (or sent to the burial grounds)? Removing equipment and sealing all riser openings with a water repellent sealant might significantly increase the time to failure.

In addition, the first tanks slated for closure do not have cooling coils. Wouldn't these tanks be ideal for the disposal of failed equipment? Pumps, piping, portions of the evaporator systems, etc., could all be dropped into the tank and disposed of (fixed in place by grout or implementing other closure alternatives). Larger equipment could be broken up at the $299 \mathrm{H}$ facility to fit into open risers. This would be a beneficial reuse of the tank space rather than sending material to the SWDF. It might add some inventory to GTS. Grouting this tank and entombing failed equipment could save money. If this Type IV closure is rushed, the opportunity will be lost. Tanks with cooling coils are not a candidate for such a beneficial reuse unless some method for remotely cutting out the coils is developed.

DOE-SR response 9: Discussions with SCDHEC have occurred on this subject. The regulators have agreed that on Tank 20, no additional equipment will be entombed into the tank. Only equipment attached to the tank (i.e. risers, pump, etc.) will remain. Putting failed equipment into a HLW tank is one of the ways in which DOE-SR will try to reduce disposal costs in the future. A management decision has been made to close the first tank (Tank 20) without this additional burden. DOE-SR is expected to close the first tank by the end of this calendar year and adding additional scope would be inappropriate at this time. Future tanks will be reviewed to see if it is in the best interest to convert these to low level waste disposal facilities which would require additional permits (including NRC permitting)

Beaumier comment 10: Page 6.5 of the closure plan discusses assumptions in GTS. What is being done (or will be done) to validate these assumptions? In particular, the sandy clays at SRS tend to bind with certain radionuclides. If there is a future plume, will radionuclides concentrate in a single area due to an ion exchange in the soil and create "hot spots"?

DOE-SR response 10: DOE-SR will monitor any futurc releases and remediate the soil if necessary. Modeling will continue to improve our knowledge about GTS and groundwater hydrology. 
DOE response to letter L-04 on pages $\mathrm{D}-7$ to $\mathrm{D}-12$
Glenn R. Beaumier

Beaumier comment 11: Page A-1 of the closure plan presents a matrix of alternatives. This matrix should not include alternatives $\mathrm{D}$ and $\mathrm{E}$ because they were not seriously evaluated and cannot be compared to the other alternatives. Page A-13 acknowledges that costs are unknown for these alternatives. I would argue that the costs assumed for alternative D are grossly exaggerated and prematurely remove this alternative from evaluation. The first tank would undoubtedly be an expensive closure, but once the equipment was purchased and techniques perfected, costs would drop rapidly. I suggest that option D be broken into several different options of increasing efficacy and cost estimates prepared so that they can be fairly compared against the other alternatives. One time startup costs should be broken out from costs incurred from each tank closure.

On page A-9, under alternative E, cleaning steps are "yet to be defined". If the steps are yet to be defined, then how can this be an alternative? I suggest that some method be selected and cost estimated so that there is a bases for comparison with other options.

Many of the methods (under alternatives $\mathrm{D}$ and $\mathrm{E}$ ) must be developed to resolve waste removal problems at Hanford. If the methods must be developed and perfected, why doesn't SRS develop them so they will be ready when needed throughout the complex? . Hanford will not be in the waste removal business for quite some time, and SRS could be the test bed for tank cleaning and waste removal,

At this time, altenative $\mathrm{C}$ has been selected. If alternatives $\mathrm{A}$ through $\mathrm{E}$ are in an increasing order of efficacy, then the alternatives on both sides of the sclected alternative should be thoroughly examined. Before making a final alternative selection, at a minimum, please present a more in depth analysis of alternative $\mathrm{D}$.

DOE-SR response 11 : It is true that the first tank in the tank closure program will be much higher in overall costs. Regulators are also interested in alternative D so DOE-SR has progressed towards an cvaluation. Further waste removal techniques and new technology may help to reduce the costs associatcd with tank closure. DOE-SR has taken an active role in this area by creating a vendor forum to look into alternate technologies for waste removal. A vendor forum was heid in June of this year. Follow-up on the practical and economical issues are ongoing. Furthermore, the Tank Focus Area committee has and will continue to evaluate DOE needs throughout the complex in regards to waste removal. SRS plans to take the lead in the tank focus area and will be the test bed for many tank cleaning demonstrations and waste removal technologies.

Beaumier comment 12: Consistent with ALARA, I did not see any real discussion on removing tank heels because it's the right thing to do. Wet/dry vacuums were briefly mentioned (page A-14) but I found no significant discussion on the merit, possibility, or feasibility of removing tank heels beyond the 3000 to 4000 gallon level. None of the alternatives discuss complete heel removal. An alternative, before and/or after, or part of alternative $C$, should be added to include heel removal. The plan does note that these technologies are not mature at this time. Why aren't 
DOE response to letter L-04 on pages D-7 to D-12
Glenn R. Beaumier

they developed and used as part of the closure process? What is the impact of waiting a few years? Why is SRS in such a rish to close the first tanks? Also, see comment 14

\section{DOE-SR response 12: (see DOE-SR response 14 below)}

Beaumier comment 13: Why is there no mention of treatments such as insitu vitrification or calcining where leaving a heel would be less of a concern?

\section{DOE-SR response 13: : (see DOE-SR response 14 below)}

Beaumier comment 14: On page A-7 of the closure plan, the no action alternative is discussed. The time frame for the analysis is not clear. How long do we have to make a decision different than the no action? Many D\&D projects (reactor buildings for example) are on hold for tens or hundreds of years to allow for rates to drop. Why isn't the same philosophy being applied here? If the primary worker dose for option $\mathbf{E}$ is $93 \mathrm{man} \mathrm{rem}$ (page A-7), primarily from Cs 137, then waiting 60 years would cut the dose to 25 man rem, would allow time for the development of remote technologies, and may be less costly due to the time value of money ls there an immediate safety concern that is driving closure of the first tank in 1996 ? It is not clear why there is such a rush. According to the EA (page 1 line 32) SRS has until at least 2028 to close the Type I, II, and IV tanks.

DOE-SR response 14:12,13, and 14 are combined answers.

SRS will use the best available technology (BAT) where possible. It would not be prudent to wait until the tank fails. Many are approaching their average life expectancy of 50 years, thus creating the urgency to close and decommission these tanks. DOE-SR is taking an active role to meet its Federal Facilities Agreement (FFA) commitments to the State of South Carolina and EPA along with the public around the Central Savannah River Area.

DOE-SR will continue to evaluate alternate treatments such as insitu vitrification or calcining where leaving a heel would be less of a concern.

Recently, Al Alms (DOE Assistant Secretary for Environmental Management) has established goal of cleaning up the tank farms within ten years. It will be an SRS goal to close all Type I, II, and IV tanks within this time period. Please note, that according to the EA and the Waste Removal Plan and Schedule, SRS will close the tanks by 2028. The DOE-SR Assistant Manager for HLW has a document $(20 / 20$ Vision) to close the tanks by 2020 . The tank closure program will try to meet all these goals in their entirety.

Beaumier comment 15: Page A-11 of the closure plan claims that spray nozzles can remove sludge from the edges of the tank, the tanks can be reslurried, and the contents pumped out. This is not true: The reason why these piles were created was due to "dead zones" in the slurry pump cleaning radii. Once the shrry pumps are restarted, the sludges will quickly resettle in the dead zoncs. The only real options are dissolution of the solids (acid washing) or some sluicing device. 
DOE response to letter $\mathrm{L}-04$

on pages D-7 to D-12
Glenn R. Beaumier

8

DOE-SR response 15: Recent videos have shown that "dead zones" are created in the areas of the slurry pump radii. In some instances, solids will resettle outside of the dead zones. Morc importantly is the performance objectives that must be met to close the tank as discussed in the tank specific closure modules.

Beaumier comment 16: The EA, page 1, line 23 claims that the best available demonstrated technology will be used to remove waste from the tanks, including the heels. This is not consistent with the closure plan where the least expensive technology that meets groundwater modeling parameters is selected. The discrepancy needs to be resolved one way or the other.

DOE-SR response 16: The introduction has been modified to include the following words: "The selection of tank system closure method will be evaluated against the following.CLRCLA critcria described in $40 \mathrm{CFR} 300.430(e(9)$ : (1) overall protection of human health and the environment; (2) compliance with applicable or relevant and appropriate requirements (ARARs); (3) long-term effectiveness and permanence; (4) reduction of toxicity, mobility, or volume through treatment: (5) short-term effectiveness; (6) implementability; (7) cost; (8) state acceptance; and (9) community acceptance." Each individual closure of a tank will be described in full detail in the tank-specific closure module.

Beaumier comment 17: Given the options considered (and the proposed alternative on grouting in place), this appears to be a major federal action. The proposed alternative will essentially restrict the use of the land in the tank farm areas (and downgradient land) for several thousand years (or "forever" via restrictions on deeds). Tank removal (closure plan page A-13) would be $\$ 50$ million times 24 tanks, or $\$ 1.2$ billion by 2028 . Either way, this looks like a major federal action that would have significant local impacts. What is the bases for an EA rather than an EIS?

DOE-SR response 17: The purpose of writing an EA, as described in National Environmental Policy Act (NEPA) regulations (40 CFR 1508.9), is to produce a document that provides "...evidence and analysis used to determine whether or not to prepare an Environmental Impact Statement (EIS)." The process followed by DOE-SR in writing this EA is consistent with the requirements of NEPA. Thus, based upon the impacts described in the EA, DOE-SR will either publish a Finding of No Significant Impact (FONSI) or prepare an EIS. The EA review process is scheduled to be completed by July 31, 1996.

Beaumier comment 18: The closure plan and EA mention that no robotic arms are available that can navigate through the forest of cooling coils. Why not have a robotic arm just cut away the cooling coils and let them drop to the bottom of the tank? Simply cutting away the coils appears to open up or make other alternatives appear more attractive.

DOE-SR response 18. The issue with the cooling coils in a tank is the ability to navigate a robot around them in order to clean the residual waste from the bottom of the tank. Cutting the coils and letting them drop to the bottom of the tank so that they would cover the waste would only make waste removal even more difficult. 
DOE response to letter $\mathrm{L}-04$ on pages D-7 to D-12

\section{Glenn R. Beaumier}

Beaumier comment 19: Lastiy, I would like to request the narne of the individual who is accountable and/or responsible for selecting a path forward be identified in the final plan. Someone, not a faceless bureaucracy; clearly needs ownership of this decision making process and must be ready to defend the technical merit of their actions. Right now, technical merit and completeness appears to have a back seat to schedule.

DOE-SR response 19: The DOE-SR Manager has the ultimate responsibility for the tank farms, the tank closure program and overall program management at the site.

We appreciate your interest and hope we have adequately addressed your concerns in this matter. If you have further questions or require additional information regarding this proposed action, I can be reached at $803 / 725-1523$.

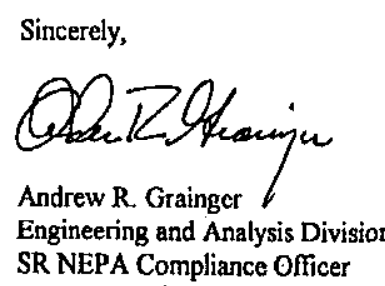

SR NEPA Compliance Officer

bc:

L. T. Ling, PROGM (Concur)

C. R. Shearer, OCC (Concur)

A. L. Towns, EQMD

M. L. Hess, WSRC, 773-42A

J. R. Giusti, OEA

AMHS\& TS Reading File

EAD Reading File

File 
Mr. Andrew $H$. Grainger

SR/NBPS Compliance Officc

Department of Energy

Savannah River Operations office

Building $/ 73-42 \mathrm{~A} / \mathrm{km}$. 212

Niken SC 20808

Dear Mr. Grainger

Re: Closure of the $F$ and $H$ Area High Level Waste Tanks

The following coraments ore offered:

1. Ceneral: I endorse Doe's general approach of finding the most practical, economical method possible for cloging these tanks.

2. Not withstanding the above comment, I feel that DOE should romplate an EIS rather than an EA even though the EA indicates the environmental impacts are small. I believe that on EIS is requlred for any signiticant Federal action that may impact the environment. At the pubise meeting, we were told that it is anticipated that ahnut 2,000 gallons of HLW will be left In each waste tank. This is equivalent to about 18 canisterg of canistered HLW (2000 gal $\times 51$ tanks/:34,000,000 gals total waste $\times 6000$ total canisters $=18.3$ canisters $)$. Based on the Tank 16/17 cleaning results, this 2,000 gallon hael may be optimlstic. It appears to be inconsistent to seek a geologir. repnsitory in Nevada away from the water table for disposal of $A$ vitrifies, canistered waste but yet to leave that much woste in South. Cornlina unvitrified, exposed to water and the eavizonment on the hasts of an RA.. Even though the environmental impacts may be small, I believe DOE should prepare an EIS to proclude second guessers.

3. EA. p.5 1.18. Add "And dispmsat" after "long-term storage" to stress the plans for eventual shipment to a reposilory.

4. EA. P.7 1. 26/32. The publicly stated goals of 2000 gallos yf weste 2000 allo your optinism?

5. EA. p.7 1.34.. Incluniling oxalic actd here implies it, will be used but the plan indicates otherwise.

6. RA p.B I. 8. The term self-levellung is used liery (and several other locotions) without sny indication of criteria. Surne indication of how much gradient, might be expecled glivuld be given. In addition, considering the hater strese on cooling codl configurstion, otc. this may be indsleading your readers. 
L-05 7. EA. p.8 1. 18. (and other locationg) State the costs in a specific Continued Fy dollars. Also, the lack of variation in costs and personnel expoticen different closure methods does not appear to bo logical.

B. EA. p. 11 1.7. CLSM is introduced without explanation.

9. EA. p. $171.21 / 43$. The engineered cap has not been previously discussed. Are the personnel exposures per tank? per 51 tanks?

10. EA. p.19 1.23. An order of magnitude variation sometimes is very significant.

Appendix $C$ should address the consequences of natural events that might rupture an empty tank allowing waste to drain into the ground water sooner than anticipated.

11. EA p.21 1.46. Shouldn't the Interoffice Memo have a document number to ensure retrievability?

12. EA, P.G1. Are the B-25 boxes constructed of gtainless steel or carion steeli?

13. CP p.2-11. Evaporator capacity needs a time unit.

14. CP p.2-12. Fig 2-4 shows 2 tanks uagd for ITP rather than 3 specsfied.

15. CP p.4-1. If sand is used as fill material, does it retard migration rates?

16. CP p.4-4. Specify what type of sampling/monitoring will be done post closure. Where? How often? Analytical techniques?

It is obvious that the tank and area closure will require large guantities of clay, sand etc. Presumably thls will be obtained on site.
Has the environmental effects of this excavation been addressed?

17. CP p.A3. With the strong grout on top, the case for easily removing the CLSM may be overstated.

18. CP p. A10/11. Comparing the waste volumes remaining in Tạnks 16 and 17 after bulk removal and spray washing, it is evident that only a factor of 2 zediction was achieved. Why not uae s second spray wash? in the tonk.

19. CP P. D2, D6, and D20. One of the most important parameters in the closure plan is the volume and composition of the residual waste in the tank. Unfortunately, DOE has provided no information in the document as to how d'Entremont arrived at his estimates of how much waste remained in the tank. Is this from sampling the sluxry and pumping to a minimum heel? Did he allow for hang-up on cooling colls? Was there any visual inspection? Was there any non-destructive
See DOE response letter

on pages D-25 to D-31 
examination of the tank for residues? What are the limits of error for the quantities? Will this limit of error be factored into the Performanmce

Objectives? If not, why not? Table D4 should be presented in both

curfes and grams so that non-technical personnel can appreciate the

mass of radioactive material remaining.

Legend: EA - Environmental Assessment Document

CP - Closure Plan

$$
\begin{aligned}
& \text { Sincerely, } \\
& \text { Eugenefere Graf }
\end{aligned}
$$

See DOE response letter on pages D-25 to D-31 
DOE response to letter $\mathrm{L}-05$ on pages D-22 to D-24

\section{Department of Energy \\ Savannah River Operations Office P.O. BoxA \\ Aiken, South Carolina 29802}

\section{JUL 241996}

Mr. Eugene L. Graf

Campbellton Drive

North Augusta, South Carolina 29841

Dear Mr. Graf:

SUBJECT: "Industrial Wastewater Closurc Plan (CP) for F- and H-Area High-Level Waste Tank System and Draft Environmental Assessment (EA) for the Closure of the High-Level Waste Tanks in F- and H-Areas at the Savannah River Site (SRS).

This is in response to your letter of July 6,1996, commenting on the stated subject. Your letter, and the following Department of Energy-Savannah River (DOE-SR) response, will be included in the Final,EA (DOE/EA-1164).

Graf comment 1: I endorse DOE's general approach of finding the most practical, economical method possible for closing these tanks.

DOE-SR response 1: No response required.

Graf comment 2: Not withstanding the above comment, I feel that DOE should complete an EIS rather than ar EA even though the EA indicates the cnvironmental impacts are small. I believe an EIS is required for any significant Federal action that may impact the environment. At the public meeting; we were told that it is anticipated that about 2,000 gallons of High-Level Waste (HLW)

will be left in each waste tank. This is equivalent to about 18 canisters of canistered HLW (2000 gal(s) $\times 51$ tanks $/ 34,000,000$ gals total waste $\times 6000$ total canisters $=18.3$ canisters $)$. Based on the Tank 16/17 cleaning results, this 2,000 gallon heel may be optimistic. It appears to be inconsistent to seek a geological repository in. Nevada away from the water table for disposal of a vitrified, canistered waste but yet to leave that much waste in South Carolina unvitrified, exposed to water and the environment on the basis of an EA. Even though the environmental impacts may be small, I believe DOE should prepare an EIS to preclude second guesses.

DOE-SR response 2: DOE-SR HLW is expecting the Nuclear Reguiatory Commission (NRC) to concur that waste remaining in each tank after waste removal and washing can be classified as residual. This will be defined as "incidental". waste which is neither high-level waste nor low-level waste. The NRC is expected to agree (by Aug. 31, 1996) that DOE-SR has effectively shown it will be able to bind and hold the remaining incidental waste through a reducing grout mixture.

Due to this ruling, it would be irrelcvant to compare what is remaining in each tank with the feed to DWPF. Furthermore, DWPF feed is separated when it is processed through $\mathrm{ln}$-Tank 
DOE response to letter $\mathrm{L}-05$ on pages $\mathrm{D}-22$ to $\mathrm{D}-24$
Mr. Eugene L. Graf

2

Precipitation (ITP) and Late Wash. The remaining waste in each tank has not been processed in this manner. Curie counts will vary widely due to this process.

Each tank will undergo analysis and this analysis of waste and its contents must meet the performance objectives set forth in the Wastewater Closure Plan. If the performance objectives cannot be met, additional washing may be needed or the tank will be closed in the future under a Comprehensive Environmental Response, Compensation, and Liability Act (CERCLA) program.

The purpose of writing an EA, as described in the National Environmental Policy Act (NEPA) regulations (40 CFR 1508.9), is to produce a document that provides "..evidence and analysis used to determine whether or not to prepare an Environmental Impact Statement (EIS)." The process followed by DOE-SR in writing this EA is consistent with the requirements of NEPA. Therefore, based upon the impacts described in the EA, DOE-SR will either publish a Finding of No Significant Impact (FONSI) or prepare an EIS. The EA review process is scheduled to be completed by July 31, 1996.

Graf comment 3: EA Page 5, line 18. Add "And disposal" after "long-term storage" to stress the plans for eventual shipment to a repository.

DOE-SR response 3: "Final disposal of the vitrified waste will proceed after the transfer to federal repository." will be inserted in the EA on page 5 line 18.

Graf comment 4: EA page 7, line 26/32. The publicly stated goals of 2000 gallon(s) of waste remaining after spray washing appears inconsistent with the 3500 and 4000 gallons quoted here for $\operatorname{tank} 16$ and 17 . What is the basis for your optimism?

DOE-SR response 4: The inventory estimate is subject to large uncertainty, so we have chosen to express it as "less than 4000 gailons." The lowest liquid level at which we have photographs of the tank is 2.0 inches, which is equivalent to 7,000 gallons of liquid. At that level, a mound of sludge in the center of the tank protrudes a few inches above the liquid surface. The depth of the sludge throughout the rest of the tank is evidently less than 2 inches, but the exact depth is unknown.

The estimate of 2000 gallons is based on the assumption that the slope of the pile is similar to the slope of the sludge surface during earlier waste removal operations at higher levels in the tank The accuracy of the estimate will be improved when we pump the liquid out of the tank.

Graf comment 5: EA page 7, line 34. Including oxalic acid here implies it will be used but the plan indicates otherwise.

DOE-SR response 5: As described in the EA, DOE-SR intends to select waste removal and stabilization processes for the tank systems on a tank-specific basis taking into account factors such as environmental requirements, technical feasibility, and cost. Oxalic acid may be used for additional cleaning as stated in both the EA (Section 2.1.1) and the CP (Section A.3.2). 
DOE response to letter $\mathrm{L}-05$ on pages D-22 to D-24
Mr. Eugene L. Graf 3

Graf comment 6: EA page 8, line 8. The term self-leveling is used here (and several other locations) without any indication of criteria. Some indication of how much gradient might be expected should be given. In addition, considering the later stress on cooling coil configuration, etc., this may be misleading your readers.

DOE-SR response 6: The term self-leveling is used in both the EA and the CP to describe a fill material mixture that is sufficiently nunny to flow and seek its own level prior to setting up. The actual levelness of the material is not a driving factor in its selection as a closure fill material.

Graf comment 7: EA page 8, line 18. (and other locations) State the costs in a specific FY dollars. Also, the lack of variation in costs and personnel exposure between different closure methods does not appear to be logical.

DOE-SR response 7: All costs are presented in FY1996 dollars. A note to that effect has been added to the EA. The costs and radiation doses were based on a detailed study conducted in 1982 on Decommissioning Alternatives For Waste Tank 16. Cost estimates were converted to 1996 dollars. This study was used because there was a logical reason for the costs and radiation doses. The "no action" alternative costs were for documentation and tank isolation. The radiation exposure of two man-rem was for tank isolation activities. Filling the tank with sand or grout costs the same, in our estimate, and results in the same radiation exposure because the level of effort and the number of workers are the same. Both require the same documentation, the same pre-filling preparations, and similar installation of filling equipment. The difference is the fill material-sand or grout. Filling with saltstone has a slightly higher dose based on the total average annual dose of 0.3 rem cstimated for a new Z-Area-like facility at the Tank Farm. The increased cost of filling with saltstone is duc to the construction of new Saltstone facilities apportioned over 51 tanks and for the increased cost of safety documentation for the new Saltstone facilitics. However, there is a savings that would be realized from fewer Saltstone vaults that is subtracted from the cost estimate for this option. The cost for the final option of removing the tank from the ground and burying it is very high because of the dismantlement equipment costs and the wastc disposal costs of burying the cut up tanks in B-25 boxes. The radiation dose estimate is high because of the increased number of people required and increased level of effort in removing and eutting up the tank.

Graf comment 8: EA page 11, line 17. CLSM is introduced without explanation.

DOE-SR response 8: The reference to Controlled Low-Strength Material (CLSM) has been removed.

Graf comment 9: EA page 17, line 21/43. The enginecred cap has not been previously discussed. (What) are the personnel exposures per tank? Per 51 tanks?

DOE-SR response 9: The discussion of a typical tank closure in Appendix B of the EA has been modified to include "engineered cap". The engineered cap is also discussed in the CP (Section 
DOE response to letter $\mathrm{L}-05$ on pages D-22 to D-24
Mr. Eugene L. Graf

A.2.1.1.2) which is reference (DOE 1996). The engineered cap is shown on Figure 2-1 (page B-2 in the $\mathrm{EA}$ ) and described in the accompanying paragraph. In the context of the paragraph on page 17 on which the comment is based, one of the scenarios modeled by the computer to determine the dose at the seepline included a clay cap to determine if it would be effective in reducing the dose at the seepline. Because of the physical arrangement of the tanks, such a cap would be installed over a group of tanks after they were closed out.

The radiation doses calculated at the scepline are for Ground Transport Segment which typically are for several tanks. For this particular case, the doses are from Tanks 17, 18, 19, 20, and 44 as described in Appendix C of the Industrial Wastewater Closure Plan for F- and H-Area.

Graf comment 10: EA page 19, line 23. An order of magnitude variation sometimes is very significant.

DOE-SR response 10: The intent of the paragraph is so show a sensitivity analysis of the various closure methods. Inspection of the modeling results revealed that the choice of closure method does not impact the amount of exposure as much as it impacts the arrival time of the contamination at the seep line.

Graf comment: Appendix $\mathrm{C}$ should address the consequences of natural events that might rupture an empty tank allowing waste to drain into the groundwater sooner than anticipated.

DOE-SR response: As shown in Figure 1-4, NEPA coverage for an empty tank (bulk waste removed) can be found under DOE/EIS-0082S and DOE/EIS-0217 where consequences of tank rupture are covered by a bounding analysis as required by NEPA. Changes to the tank configuration as previously analyzed (as it relates to tank rupture) begins for this action with the addition of grout to the empty tank. An empty tank under this action is no different than an empty tank covered by DOE/EIS-0082S and DOE/EIS-0217.

Graf comment 11: EA page 21, line 46. Shouldn't the Interoffice Memo have a documen number to ensure retrievability?

DOE-SR response 11: As required by the NEPA regulations the Interoffice Mcmo has been filed in the DOE-SR reading rooms under HLW-HLE-96-0225.

Graf comment 12: EA page G-1. Are the B-25 boxes constructed of stainless stcel or carbon stcel?

DOE-SR response 12: Most B-25s are carbon steel. Some of the newer ones are stainless steel having been made from.reactor heat exchangers under the beneficial reuse program. The word stainless has beer removed from the sentence.

Graf comment 13: CP page 2-11. Evaporator capacity needs a time unit. 
DOE response to letter $\mathrm{L}-05$ on pages D-22 to D-24
Mr. Eugene L. Graf

DOE-SR response 13: The $2 \mathrm{~F}$ and $2 \mathrm{H}$ evaporator vessels have an operating capacity of 1800 gallons each. The average evaporate per day is approximately 4950 gallons for the $2 \mathrm{~F}$ evaporator and 5700 gallons for the $2 \mathrm{H}$ evaporator.

Graf comment 14: CP page 2-12. Figure 2-4 shows 2 tanks used for ITP rather than 3 specified.

DOE-SR response 14: Figure 2-4, General layout of H-Area Tank Farm shows the ITP Process Area as consisting of the ITP process building and four tanks (Tanks 48-51). More specifically, Tank 48 has been used to prepare feed to ITP and used as the connection tank for inter-area transfers to ITP from F-Area. This tank is the primary salt tank used to feed to the filter building in ITP. Tank 49 contains the washed precipitate (contaminated) in the ITP process. Tank 50 receives the Effluent Treatment Facility water concentrate that will need to be filtrated through ITP. Tank $5 I$ is part of ITP and the Extended Studge Processing in which low aluminum will be held for later processing.

Graf comment 15: CP page 4-1. If sand is used as fill . matcrial, does it retard migration rates?

DOE-SR response 15: Sand is relatively inert and could not be formulated to retard the migration of radionuclides and chemical constituents. Therefore, the expected contamination levels in groundwater would be higher than for the selected alternative (i.e. grout). More specifically, modeling results indicate a $24 \%$ decrease in the total radiation dose at the seepline for grout fill verses sand.

Graf comment 16: CP page 4-4. Specify what type of sampling/monitoring will be done post closure. Where? How often? Analytical techniques?

It is obvious that the tank and area closure will require large quantities of clay, sand, etc. Presumably this will be obtained onsite. Has the environmental effects of this excavation been addressed?

DOE-SR response 16: Sampling/monitoring for each individual tank will be completed after closure. Each tank will be considered separately in the tank-specific closure module which will describe where, how often, for how long, and what techniques will be used to complete the task. In general, the DOE-SR Environmental Quality Management Division is responsible for monitoring of surface and groundwater contaminants after the closure of the tanks.

After closing the individual tanks, the tank farm areas will be closed under a Comprehensive Environmental Response; Compensation, and Liability Act closure plan. If an enginecred cap is required, any cap construction material excavated onsite will be NEPA evaluated at that time.

Graf comment 17: $\mathrm{CP}$ page $\mathrm{A3}$. With the strong grout on top, the case for casily removing the CLSM may be overstated. 
DOE response to letter $\mathrm{L}-05$ on pages D-22 to D-24
Mr. Eugene L. Graf

DOE-SR response 17: CLSM is widely used as a backfil material at SRS. On top of the CLSM, a strong grout will help discourage an intruder from accidentally accessing the waste tank contents and tank structures if and when institutional control of the area is discontinued. Removing the smaller top layer of grout would be more challenging than removing the bulk of the tank filler (CLSM). The intention of the top layer is to defer entry into the tank and was designed to not be easily removal or penetrable.

Graf comment 18: CP page Al0/11. Comparing the waste volumes remaining in Tanks 16 and 17 after bulk removal and spray washing, it is evident that only a factor of 2 reduction was achieved. Why not use a second spray wash? This additional wash step would further reduce the residual waste left in the tank.

DOE-SR response 18: Both tank 16 and tank 17 were spray washed twice. However, in both tanks the inventory after spray washing cannot be estimated with much precision because in both cases much of the tank floor was covered with several inches of water. Tank 16 was eventually dried after oxalic acid cleaning, but the inventory after spray washing was not precisely determined. And, as previously mentioned, tank 17 has never liad less than 2 inches of water.

Therefore, the spray washing estimates in the $\mathrm{CP}$ are conservative. The actual inventories after spray washing are probably smaller then reported, perhaps by a factor of 2 , and the actual improvement by spray washing may be higher than reported, perhaps a factor of 4 . At the time spray washing was completed in these tanks, in the late 1970 s and early 1980 s, the main concern of waste removal was removing the bulk of the waste from the tank, so there was minimal incentive to determine the exact residual.

In each tank that is scheduled to be closed, plans are to completely pump out the liquid so that the quantity of residual waste can be accurately determined. For example. Tank 20 was recently pumped down. The residual has been shown to be less than 1000 gallons, and further inspections are planned to improve the accuracy of this estimate (Tank 20 was a salt tank. Larger residuals are expected in sludge tanks).

In tanks where the residual is large, additional spray wash operations or further treatment, such as oxalic acid cleaning, will be performed in order to meet performance objectives. It is not reasonable to specify the proper number of spray washes at this time. As more experience is obtained in waste removal, the process will become better defined.

Graf comment 19: CP page D2, D6, and D20. One of the most important parameters in the CP is the volume and composition of the residual waste in the tank. Unfortunately, DOE has provided no information in the document as to how d'Entremont arrived at his estimates of how much waste remained in the tank. Is this from sampling the slurry and pumping to a minimum heel? Did he allow for hang-up on cooling coils? Was there any visual inspection? Was there any non-destructive examination of the tank for residues? What are the limits of effort for the quantities? Will this limit of error be factored into the Performance Objectives? If not, why not? 
DOE response to letter $\mathrm{L}-05$ on pages D-22 to D-24
Mr. Eugene L. Graf

Table D4 should be presented in both curies and grams so that non-technical personnel can appreciate the mass of radioactive material remaining.

DOE-SR response 19: All of the estimates cited for tanks 16,17, and 20 are based on photographic inspections of the tank interiors taken after spray washing and oxalic acid cleaning. There was no other type of testing. Photographs taken after spray washing in each tank show waste only or the floor of the tank. In tank 16, no waste was observed on the cooling coils, waste only on the floor of the tank. In tank 16 , no waste was observed on the cooling coils,
walls, or roof. Tanks 17 and 20 have no cooling coils; no waste was observed on the walls or roof.

The estimates for tanks 16 and 17 were based on sludge observed at the bottom of the tank. The volume was estimated based on the areal extent of the sludge and the estimated depth; however, as noted previously, the accuracy of this technique is limited because in each case, much of the surface of the sludge was underneath the liquid surface and was therefore not visible. In tank 20, only 3.5 inches of liquid was observed after spray washing. Therefore, the estimate of "less than 1000 gallons" was an educated guess, although it has been confirmed when the liquid was pumped out.

Plans are to pump down each waste tank after waste removal as much as possible and estimate the quantity of waste remaining. The intent is to estimate the quantities conservatively (e.g. "less than 2000 gallons," "less than 500 gallons"). This is equivalent to a one-sided error bar. As long as this conservative estimate is adequate, there are no plans to estimate the actual quantity and estimate the end points of a two-sided error bar (e.g. " 500 gallons $+/-200$ gallons").

We appreciate your interest and hope we have adequately addressed your concerns in this matter. If you have further questions or require additional information regarding this proposed action, I can be reached at $803 / 725-1523$.

Sincerely,

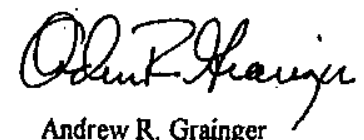

Andrew R. Grainger

Engineering and Analysis Division

SR NEPA Compliance Officer 


\section{Gtate of}

(B)ffice of the Bausernor

Dangmigentio

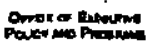

June 28, 1996

Mr. A. R. Grainger

Engineering and Analysis Division

NEPA Compllance Offles

Sevannah RJver Operations Offlce

Post Office Box A

Alken, South Caroline 29802

Project Name: Environmintal Assassment (EA) for the Closure of the High Level Waste Tanks in F-B-H-Areas at the gavannah Rlver Site (SRS)(DOE/EA-1164

Project Number: EIS-96060i6-016

Dear Mr. Grainger,

The Grant Services Unit, Office of the Governor, has conducted an intergovernmental review on the above referenced actlvity as provided by Presidentlal Execultve Order 12372. All comments received os a result of the review are enclosed for your use.

The State Application Identifler number indicated above should be ured in any future correspondence with this offlee. If you have any questions call me at (803) 734-0485.

Sincerely,

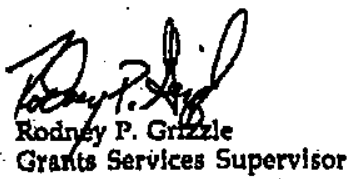

Bridosures 


\section{GLOSSARY}

Annulus. Ringlike structure around a primary containment.

B-25 Box. Steel box used to contain radioactive waste for burial.

Bulk Waste. The major fraction of waste in a tank. It can be removed by conventional means (eg., pumping).

Cap. An impermeable layer of material placed over an area to reduce the amount of rain water migrating down through the soil and carrying away contaminants into the groundwater. Caps are often constructed of layers of clay, gravel, and vegetated topsoil.

Controlled Low Strength Material. A self-leveling, pumpable, concrete composed of sand and cement formers.

E-Area Vault. Project which consists of several types of facilities (i.e., below-grade concrete structures, on-grade concrete structures within excavated areas) that will dispose of designated waste types (low-activity, intermediate-level tritiated and nontritiated, and long-lived waste) of low radioactive waste materials.

Fission Products. Nuclei from fission of heavy elements (primary fission products); also, the nuclei formed by the decay of primary fission products, many of which are radioactive.

Groundwater. The supply of fresh water under the Earth's surface.

Grout. Cement-like mixture which is pumpable, easily flows into voids, and hardens upon setting.

Heel. The residual amount of waste left on the bottom of a tank which cannot be practically removed.

High-Heat Waste. Freshly generated waste that contains a large concentration of shortlived radioactive radionuclides from the first extraction cycle of a separations process. High-heat waste (HHW) is aged to allow radioactive decay to prevent the potential discharge of harmful levels of radiation.

Insoluble Sludge. A thick layer of various heavy metals and long-lived radionuclides that will not dissolve and that separate out of the waste over time and settle to the bottom of the waste tank.

Leachate. Liquid that has percolated through solid waste of other media and that contains dissolved or suspended contaminants extracted from those materials.

Leaching. The process in which a soluble component of a solid or mixture of solids is extracted as a result of percolation of water around and through the solid.

Low-Heat Waste. Second or subsequent extraction cycle waste generated from a separation process. Low-heat waste (LHW) contains few radionuclides and does not require aging (radioactive decay). Low-heat waste is also generated in reactor areas, the Defense Waste Processing Facility, and other SRS production support facilities. (See highheat waste) 
Outcropping. Place where groundwater is discharged to the surface. Springs, swamps, and beds of streams and rivers are outcrops of the uppermost water table.

Permeability. Ability of rock, soil, or other substance to transmit a fluid.

Person-rem. The radiation dose to a given population; the sum of the individual doses received by a population segment.

Pumpable Backfill. A grout -like mixture. By controlling the amount of hydrating materials used, the strenght of the set can be varied from strong (concrete) to moderate (comparable to hard soil).

rad. Unit of absorbed dose deposited in a volume of material.

rem. Unit of dose equivalent (absorbed dose in rads $\mathrm{x}$ the radiation quality factor). Dose equivalent is frequently reported in units of millirem (mrem) which is one-thousandth of a rem.

Saltcake. Concentrated waste in the form of crystallized salts resulting from the evaporation of liquid high-level waste.

Saltstone. Low radioactivity fraction of high-level waste mixed with cement, flyash, and slag to form a concrete block.

Seepline. Place where groundwater discharges or outcrops to the surface, often near creeks and streams.

Sludge. The precipitation solids (primarily oxides and hydroxides) that settle to the bottom of the storage tanks containing liquid high-level waste.

Slurry. A suspension of solid particles (sludge) in water.

Supernate. The radioactive layer of highly mobile liquid containing soluble salts; the supernate remains above the saltcake and/or insoluble sludge in a waste tank.

Tank Farm. An installation of (usually interconnected) underground tanks for the storage of high-level radioactive liquid wastes.

Transuranic. Alpha-emitting elements heaver than uranium.

Vadose Zone. Soil zone located above the water table. 


\section{Acronyms and Abbreviations:}

$\underline{\text { Acronyms }}$

CERCLA Comprehensive Environmental Response, Compensation, and Liability Act

CLSM

DBA

DOE

DWPF

EA

EIS

EPA

ESP

ETF

FFA

FHT

Controlled Low-Strength Material

Design Based Accidents

Department of Energy

Defense Waste Processing Facility

Environmental Assessment

Environmental Impact Statement

Environmental Protection Agency

Extended Sludge Processing

Effluent Treatment Facility

Federal Facility Agreement

HHW

Filtrate Hold Tank

HLW

High-Heat Waste

ITP

LHW

High Level Waste

In-Tank Precipitation

LRWHF Liquid Radioactive Waste Handling Facilities

MOA

Low-Heat Waste

NEPA

Memorandum of Agreement

NPDES

RCRA

National Environmental Policy Act

National Pollutant Discharge Elimination System

SCDHEC

Resource, Conservation, and Recovery Act

SMDF

SRS

South Carolina Department of Health and Environmental Control

STPB

Saltstone Manufacturing and Disposal Facility

Savannah River Site

Sodium Tetraphenylborate

Abbreviations for Measurements

$\begin{array}{ll}\mathrm{ft} & \text { Feet } \\ \mathrm{gal} & \text { Gallon } \\ \mathrm{ha} & \text { Hectare } \\ \mathrm{hr} & \text { Hour } \\ \mathrm{km} & \text { Kilometer } \\ \mathrm{L} & \text { Liter } \\ \mathrm{m} & \text { Meter } \\ \mathrm{mi} & \text { Mile }\end{array}$

